\title{
Accounting Discretion and the Market Disciplining of Bank Risk-taking Behavior: An Assessment of the Effectiveness of Egyptian Banking Reforms from an Accounting Perspective
}

\author{
Mohamed A. Elbannan ${ }^{1}$ \\ ${ }^{1}$ Department of Accounting, Faculty of Commerce, Cairo University, Orman, Giza 12613, Egypt \\ Correspondence: Mohamed A. Elbannan, Department of Accounting, Faculty of Commerce, Cairo University, \\ Orman, Giza 12613, Egypt.
}

Received: May 1, 2016

Accepted: June 25, 2016

Online Published: July 14, 2016

doi:10.5430/afr.v5n4p1

URL: http://dx.doi.org/10.5430/afr.v5n4p1

\begin{abstract}
The purpose of this study is to empirically delineate significant economic consequences associated with observable differences in discretion permitted to banks under the existing Egyptian Banking Act. More specifically, the study investigates whether accounting discretion is associated with earnings quality and risk-taking in the Egyptian banking sector. In light of this increased accounting discretion caused by the banking reforms, the study questions the extent to which the Egyptian banking reforms facilitate market disciplining of banks. Based on a sample of 46 banks providing 634 bank-quarters over the period 2000-2015, the results indicate that, during non-crisis (crisis) years, bank managers smooth out earnings leading to higher quality earnings but also to higher (lower) earnings volatility and (lower) bank risk, consistent with the managerial efficiency and not managerial opportunism explanation of accounting discretion. It is concluded that the economic reforms created conditions whereby bank earnings attributes are improved but where prudential market monitoring and oversight over bank risk-taking behavior may suffer.
\end{abstract}

Keywords: Banks, Market Discipline, Accounting Discretion, Earnings Attributes, Risk-Taking

\section{Introduction}

The purpose of this study is to empirically delineate significant economic consequences associated with observable differences in discretion permitted to banks under the existing Egyptian Banking Act (88/2003). More specifically, the study investigates whether accounting discretion is associated with earnings quality and risk-taking in the Egyptian banking sector. Bank discretionary loan loss provisions (LLP) continues to draw the attention of regulators and market participants (Hamadi, Heinen, Linder, \& Porumb, 2016; Jin, Kanagaretnam, \& Lobo, 2016; Ma \& Song, 2016) due to the large magnitude these provisions have on bank financial condition and profitability. Since the early 2000s, the Egyptian banking reforms have been underway to modernize the banking sector and improve its ability to meet the growing financing needs of an emerging economy. These reforms were successful in consolidating the sector into larger, more adequately capitalized financial institutions, with widely divergent ownership and governance structures, that are capable of maintaining healthy minimum capital requirement rules. Indirectly, the reforms also resulted in widely divergent discretionary accounting practices due to the diversity in bank ownerships, governance structures and operating philosophies brought about by the reforms.

In light of this increased accounting discretion caused by the banking reforms, study questions the extent to which the Egyptian banking reforms facilitate market disciplining of banks. Market participants are better able to discipline bank managers when the quality of accounting information improves and vice versa. To determine whether the reforms facilitate market discipline of banks, the study examines the differential impact of accounting discretion on the quality of accounting information reported by banks and the risk-taking behaviors of bank managers. In doing so, the question is raised regarding whether the incentives underlying discretionary accounting practices in Egyptian banks are mostly opportunistic or efficient (Christie \& Zimmerman, 1994) (Note 1). Prior literature is mixed on whether higher accounting discretion is beneficial or detrimental to the interests of capital market participants (Bowen, Rajgopal, \& Venkatachalam, 2008). However, positive accounting theory studies contend that discretion may be either opportunistic or efficient (Note 2). If discretion is opportunistic (that is, impairs earnings quality and 
increases bank risk), then an unintended consequence of the reforms is deterring market disciplining of banks, because market (and regulatory) disciplining requires transparent accounting information. If, on the other hand, discretion is efficient (improves fundamental earnings attributes and reduces risk), then the reforms successfully managed to facilitate market discipline.

Based on a sample of 46 banks providing 634 bank-quarters over the period 2000-2015, the results indicate that, during normal years of operations, bank managers engage in accounting discretionary activities (related to loan loss provisioning) that improve the persistence, predictability and smoothness of earnings but that this improvement in earnings attributes come at the expense of higher earnings volatility. On the other hand, during years of economic or political crises, accounting discretion is associated with higher persistence, lower predictability and volatility and has no effect on smoothing. Therefore, it may be argued that accounting discretionary behavior of bank managers has different goals during the non-crisis and crisis periods. During the non-crisis period, managers use their discretion to create a smooth stream of earnings that increases persistence and predictive value of the reported figures, with little concern for controlling earnings volatility. However, during the crisis period, bank managers shift their attention to the reduction of the earnings volatility caused by the crisis, leading to higher earnings persistence and lower volatility, but predictability suffers because smoothing activities taken in previous years were interrupted by the crisis. This interpretation of managers' discretionary behavior is consistent with managerial efficiency and not managerial opportunism explanation of accounting discretion.

Next, the study examines the impact of accounting discretion on market disciplining of bank risk-taking, and finds that accounting discretion is associated with higher bank risk-taking behavior and hence less market disciplining over bank risk-taking activities, during the non-crisis period. In line with the managerial efficiency perspective, managers use their discretion to smooth earnings out and, in doing so, their practices increase earnings volatility and information risk and degrades transparency. Risk-taking is dependent on the attributes of the information that provide the basis for decision making. Despite the higher earnings persistence and predictability, the higher earnings volatility increases bank risk-taking and impairs the market disciplining of bank risk-taking. On the other hand, during the crisis periods, the use of increased accounting discretion is associated with lower risk, because discretion involved in stabilizing earnings during crisis periods reduce earnings volatility, information risk and consequently bank risk-taking. Specialization in operations is also found to have an exacerbating or mitigating effect on the relation between accounting discretion, earnings attributes and bank risk-taking.

On the basis of these findings, it is concluded that the economic reforms created conditions whereby bank earnings attributes are improved but where prudential market monitoring and oversight over bank risk-taking behavior may suffer. As a strong complement to the Central Bank of Egypt (CBE) regulatory oversight, market discipline does not seem to benefit from the level of discretion allowed to bank managers under the Egyptian Banking Act, which resulted in higher quality for reported bank accounting information. Market participants are faced with greater risk (in non-crisis times) due to managers' earnings smoothing activities. Overall, the study points at an interesting pattern of rational accounting discretionary behavior that is moderated by bank specialization and the presence of a crisis period.

This study complements several recent and previous studies that examine banks' accounting discretion. Using a cross-country sample, Hamadi, Heinen, Linder, and Porumb (2016) argue that Basel II is associated with less income-increasing discretionary LLP and less income-smoothing via discretionary LLPs, which enhances the informational content of these LLPs about future loan losses and leads to higher market valuation of discretionary LLPs. Ma and Song (2016) examines the relation between earnings management through discretionary LLPs and systemic risk in the U.S. banking sector and find that earnings management increases a bank's contribution to systemic crash risk and systemic distress risk. Jin, Kanagaretnam, \& Lobo (2016) find that banks that had higher abnormal LLP prior to the 2007-2009 crisis engaged in less risk taking during the pre-crisis period and had a lower probability of failure during the crisis period.

The three recent papers, however, fail to identify the effects of discretionary LLPs on earnings attributes other than accruals, and the first two do not take into consideration the managerial incentives behind engaging in discretionary LLP practices. In contrast, Bushman and Williams (2012) find evidence consistent with discretion impairing transparency of banks and hence weakening market discipline exercised over bank risk taking. However, they use a measure of accounting discretion that is tautological with income smoothing, which may render their results spurious. Huizinga and Laeven (2009) suggest that banks use discretion to overstate the value of distressed assets, and that banks with large exposures to mortgage-backed securities recorded less LLPs in the U.S. during 2007-2008. Finally, Vyas (2009) shows that exposure to risky assets is reflected in stock prices on a timelier basis for more transparent 
banks during the financial crisis.

The paper makes a number of timely contributions to the extant literature and has policy implications for future regulatory developments in the banking industry. First, it complements and extends the literature on the role of market discipline in the regulation of banks (Bushman and Williams, 2012; Hamadi, Heinen, Linder, \& Porumb, 2016; Ma and Song, 2016; Nier \& Baumann, 2006; Rochet, 2005). Market discipline seeks to provide a role for market participants in disciplining bank activities in line with the Basel II Accord. Second, the study uses a unique context to examine the proposed relations. The Egyptian banking sector has shown resilience in the face of economic and political downturns, but the risky environment within which it operates makes it an ideal setting for studying the impact on risk compared to other settings where risk is only systematic. Third, the impact of discretionary LLP on bank risk-taking through its effects on earnings informational attributes has not been studied previously. Other studies relate discretion and accruals but do not consider these attributes. Fourth, the study argues that the objectives behind discretionary activities are context-based. That is, during crises periods, banks may use accounting discretion to contain volatility, whereas during non-crisis period discretion is exercised for smoothing out earnings.

The rest of the paper is organized as follows. Section 2 puts the paper in context relative to the extant research on bank accounting and transparency, and also on the role of market discipline as complementary aspect of bank regulation and develops the study hypotheses. Section 3 presents the sample and defines the main variables. Section 4 presents main empirical analysis on the relations between accounting discretion, earnings attributes and the discipline of bank risk-taking. Section 5 reports the empirical results. Section 6 concludes.

\section{Literature Review and Hypotheses Development}

In this section, the related literature is reviewed and the hypotheses are developed.

\subsection{The Institutional Environment of the Egyptian Banking Sector}

In 2003, Egypt started implementing an ambitious reform program to bring the competitiveness of its financial services sector to international levels. The reforms involved reducing the predominance of state-owned banks, allowing for more active foreign ownership, and facilitating stronger regulatory and market disciplining of banks. As part of the reforms, the Egyptian Banking Act No. 88/2003 was enacted requiring banks to maintain a minimum capital that is based on risk of assets held (as required under the Basel Accords (Basel Committee on Banking Supervision, 2001) (Note 3)). The Egyptian Banking Act stressed the supervisory role of the CBE in instituting regulatory monitoring and disciplining mechanisms for bank risk-taking behaviors.

Risk faced by banks have steadily increased because the reforms liberalized deposit and lending rates, increased the range of allowable service offerings and allowed banks to set their own service fees, and relaxed previous restrictions on foreign ownership. Thus, while the Egyptian Banking Act managed to create stronger entities that are capable of providing full-scale services to clients, it may have raised risk levels borne by these entities. Bank managers have to establish more forward-oriented strategies to deal with a more complex banking environment characterized by diverse ownership structures, product offerings, and attitudes towards risk.

Implicit in the Egyptian Banking Act is the implementation of current Basel Accords, which, in addition to stressing effective regulatory (i.e., central bank) disciplining of banks, also stress the private monitoring of bank risk-taking activities. To facilitate private market monitoring, these Accords require banks to provide full disclosure of the economic impact of their operations. Egyptian banks are required to follow the accounting and auditing requirements and guidelines set by the CBE, which requires banks to follow Egyptian Accounting Standards (EAS) in preparing their financial information (Note 4). The latitude allowed by the IFRS-based EAS enables managers to exercise judgement in preparing financial statements. Whether managers exercise such discretion in an opportunistic or efficient manner is a question of positive accounting research that is still largely unanswered (Christie \& Zimmerman, 1994). In particular, do self-interested opportunistic managers systematically abuse accounting discretion allowed under EAS in order to increase their wealth at the expense of shareholders? Or do managers, in general, exercise accounting discretion in an efficient manner consistent with long-run shareholder value maximization?

Furthermore, the growing diversity in ownership bases (into more foreign and institutional owners) and in the operating philosophies of banks create differences among banks with respect to how they account for their operations. Accounting differences among banks are not only due to the use of different parent entity methods of accounting (e.g., for loans and LLPs) and information technologies, but also in the degree of discretion that managers are allowed in setting accounting methods, estimates and timing. While banks still comply with full disclosure rules, this accounting discretion may negatively affect the comparability and usefulness of financial information and eventually hinder market disciplining of banks. 


\subsection{Information Transparency and the Market Disciplining of Bank Risk-Taking}

Regulatory discipline may not prevent banks from taking excessive risk. Effective market discipline complements regulatory discipline in monitoring and directing bank managers' risk-taking strategies (Nier \& Baumann, 2006; Rochet, 2005). Market discipline (private monitoring) refers to actions of shareholders, creditors, and counterparties that affect investment, operational, and risk-taking decisions (Flannery, 2001). Barth, Caprio, and Levine (2004) examine the regulations requiring information disclosure and private sector monitoring of banks and find that regulatory features that require accurate information disclosure and facilitate private-sector oversight of banks increase bank performance and stability.

Financial reporting provides useful information about the financial condition and profitability of banks that investors can use in their resource allocation decisions and that regulators can use in their role of prudential oversight of financial institutions. Both the Basel Accords and the Egyptian Banking Act view transparent financial accounting information as instrumental in the prudential oversight of banks and the facilitation of market discipline, hence examining attributes of this information is a logical first step in investigating moral hazard issues at banks. Nier and Baumann (2006) suggest that higher bank transparency promotes lower risk of default by holding larger capital buffer. Other studies suggest that transparency in matters such as interest-rate gap, notional amounts of derivatives and market-risk disclosures are viewed by the capital market participants as risk relevant (e.g., Berger \& DeYoung, 1997; Flannery \& Thakor, 2006) (Note 5).

While adequate transparency increases the ability of market participants to assess future bank performance and risk, inadequate transparency indicates that these participants will incur additional information acquisition cost. Furthermore, in addition to its ex-post effect on bank risk-taking, transparency may have an ex-ante disciplinary effect on bank risk taking activities because managers will expect that investors may demand higher returns on their uninsured investments in response to greater risk-taking by managers (Bushman \& Williams, 2012). Discretionary accounting practices of managers bear an important weight in the usefulness of financial reports. Accounting choice involves managers deciding on accounting methods and estimates and the timing of recognition for losses. Loan loss provisioning is one of the main areas of accounting choice in financial institutions that involve considerable subjective judgment in its determination. The determination of the LLP can significantly influence the attributes of bank earnings as they reflect risk of loan assets. Two competing theories emerged on the managerial incentive behind increased accounting discretion; discretion may be used efficiently or opportunistically.

Increased discretion has the advantage of providing an efficient venue for managers to signal private information about the entity's future performance (Arya, Glover, \& Sunder, 2003; Subramanyam, 1996). Managers may use this discretion to provide valuable private information about expected loan losses into provisioning decisions. Empirical evidence in Subramanyam (1996) argue that managers exercise their discretion to improve the ability of earnings to reflect fundamental value. If this is the case, then, earnings management may be beneficial to the long-run stockholder value and to the public.

However, discretion has the potential disadvantage of raising the likelihood for opportunistic accounting practices by bank managers, leading to deterioration in the attributes and transparency of bank financial information. Prior research shows mixed results on the use of LLPs for earnings management purposes (Fonseca \& Gonzalez, 2008; Liu \& Ryan, 2006). Thus, earnings management can be viewed as either opportunistic or beneficial. The extant empirical evidence in the literature is somewhat ambiguous. This study complements prior literature by documenting significant consequences of variation in discretion in loan loss provisioning practices in an emerging economy.

\subsection{Accounting Discretion and Earnings Attributes}

Earnings quality has been defined as the extent to which reported earnings faithfully represent economic income. Extant research suggests certain earnings quality constructs as proxies for earnings quality: persistence, predictive ability, volatility and smoothness (Francis, LaFond, Olsson, \& Schipper, 2003; Schipper \& Vincent, 2003), which equally apply in a financial institution setting. Earnings are said to be of higher quality when it is more persistent, more predictable, more smooth, and less volatile (Dechow \& Dichev, 2002; Richardson, 2003).

\subsubsection{Earnings Persistence}

Earnings persistence is a qualitative characteristic of earnings (Schipper \& Vincent, 2002), which refers to the extent to which an unexpected earnings surprises cause investors to revise their future earnings expectations (Richardson, 2003). Since academic theory on the impact of discretion is still ambiguous as to whether it is opportunistic or beneficial, accounting discretion may have a negative or a positive effect on persistence.

Through accounting discretion, managers may deliberately impose accounting practices that result in accounting 
earnings that does not reflect the bank's underlying economic reality and that lead to earnings surprises that impede earnings persistence. Unexpected earnings surprises consist of persistent and transitory components. Persistent earnings help market participants in revising their expectations of future earnings and cash flows while transitory earnings do not affect expectations (Richardson, 2003). Since accounting discretion through LLP is more likely to affect the transitory, rather than the persistent, component of earnings, it significantly hinders the ability of banks' financial information to reflect fundamental risk attributes of the underlying loan portfolios. As a result, increased discretion may reduce the persistence of earnings, rendering it difficult to draw conclusions about the economic consequences of bank risk-taking behavior, and hinder the market disciplining of this behavior. If this theory holds true, the relation between discretion and persistence is expected to be negative.

Alternatively, discretion may be a vehicle that managers use to stress the permanent components of income and to use the transitory components sporadically. That is, managers may use their private information in directing their LLP discretionary practices into reflecting their fundamental value (Subramanyam, 1996) and strengthening the serial autocorrelation of income across reporting periods. If this theory holds true, the relation between discretion and persistence is expected to be positive.

\subsubsection{Earnings Predictability}

Earnings predictability (or predictive ability) refers to the extent to which a firm's past earnings is associated with its future cash flows, with banks that have highly predictable earnings possessing higher earnings quality. Predictability is a desirable qualitative characteristic of accounting information. Prior research finds that entities with more predictable earnings have higher analyst forecast accuracy and lower risk premium in capital markets because higher predictability is seen as a vehicle for increasing transparency of financial information (Graham, Harvey, \& Rajgopal, 2005). Since capital market participants can predict future earnings more readily for entities with more predictable earnings, the uncertainty surrounding their earnings tends to be lower and this translates into lower cost of capital (Affleck-Graves, Callahan, \& Chipalkatti, 2002; Crabtree \& Maher, 2005). Unlike non-financial firms, banks are more sensitive to issues of transparency and uncertainty due to the inherently opaque nature of their operations (Diamond, 1996), growing complexity of operations, and their dependence on large degree of leverage. Investors are interested in information regarding the types and maturities of bank deposits in relation to those of loan portfolios. Fair values of assets and liability financial instruments provide valuable information on bank liquidity and risk.

The relation between discretionary LLP and earnings predictability stems from the fact that both constructs are endogenous to managerial discretionary behavior. Discretionary LLP is set by managers as a function of contemporary factors such as managerial compensation and bank performance. The level of LLP directly affects bank stockholders' equity through income but extant research finds that discretionary loan-loss provisions are negatively related to capital (Fonseca \& Gonzalez, 2008; Liu \& Ryan, 2006), implying that the level of discretionary LLP is potentially used to report deliberately higher or lower capital levels than current operations warrant. Thus, higher levels of discretionary LLP are expected to reduce the relation between prior and current earnings and render earnings less predictable. Alternatively, as argued for persistence, a positive relation may exist between discretion and predictability if managers use this discretion in making contemporaneous income more in line with prior periods' incomes, hence increasing the predictive value of the reported information.

\subsubsection{Earnings Volatility}

Earnings volatility refers to the degree of variability in earnings and has been linked to a wide variety of business issues related to bank risk. Extant research documents that earnings volatility has a negative relation with analyst forecast accuracy (Luttman \& Silhan, 2011) and has a positive relation with bid-ask spreads and cost of capital (Easley and O'Hara, 2004). Market participants see volatility of earnings as a warning signal that potentially requires market and/or regulatory disciplinary action. A clear understanding of the components of earnings (and the processes behind those) that drive variability upwards is necessary for sound bank management.

Bank size and diversification into nontraditional banking activities may provide incentives for accounting discretion and consequently result in higher volatility. Smaller banks are typically less diversified in terms of services and clients, and hence are forced to lend funds to a smaller borrower base of relatively lower credit risk or more collateral (Stever, 2007) (Note 6). This tends to makes these banks vulnerable to operating growth and risks of their clients. Likewise, dependence on nontraditional fee-based and non-interest activities, e.g., mutual fund sales, data processing services, mortgage servicing, is associated with increased portfolio earnings variance because these activities are normally associated with low switching costs on the part of the clients as compared to relationship lending (De Young \& Roland, 2001; Stiroh, 2004, 2006a,b). The shift to nontraditional activities is expected to increase the severity of accounting discretion because of the larger number of relatively smaller activities in comparison to 
traditional (lending) activities, which makes accounting discretion more difficult to detect.

As argued with earnings predictability and persistence, the relation between discretion and volatility may be positive or negative. First, higher accounting discretion that involves systematic (opportunistic) manipulation of earnings to meet managerial incentives is expected to increase the variability in income. Bank managers may use discretionary LLP to report earnings that are not justified given the innate drivers of performance, which would therefore weaken the relation between prior and current earnings and increase the volatility of bank earnings. Alternatively, bank managers who use discretion efficiently into bringing contemporaneous income in line with prior periods' income may actually cause volatility of earnings to diminish.

\subsubsection{Earnings Smoothness}

Earnings smoothness refers to the use of accruals to smooth fluctuations in earnings over time. Earnings smoothness is not intended to maximize or minimize income as in other forms of earnings management. It is intended to introduce transitory components to the income series in order to decrease time-series variability and increase earnings predictability (Schipper \& Vincent 2003). Researchers examined potential conditions that increase the probability of smoothing and find that managers undertake earnings smoothing for signaling a more stable future stream of income, meeting managerial self-interest incentives, reducing the entity's perceived risk, meeting tax incentives, and/or minimizing bankruptcy concerns (Cohen, Cornett, Marcus, \& Tehranian, 2014).

Prior research finds a positive relation between LLPs and bank earnings (Fonseca and Gonzalez, 2008; Huizinga and Laeven, 2009; Lobo \& Yang, 2001). These studies are based on the capital management hypothesis, which suggests that a positive relation between LLP and earnings may arise because banks minimize the cost of complying with minimum capital requirements. Other studies analyze the cyclical patterns of bank LLP and find that LLP are negatively related to GDP growth, and that this effect is partially mitigated by income smoothing practices (Laeven \& Majnoni, 2003; Bikker \& Metzemakers, 2005). Bank managers may exercise accounting discretion to the extent that they meet the minimum capital regulatory requirements imposed by the Egyptian Banking Act.

Prior literature also uses the signaling effect to suggest that bank ownership is an important driver of income smoothing. Publicly traded banks are typically owned by a large number of outsiders who are more dependent on bank financial statements for financial information. Public banks have the incentives to smooth earnings to improve the bank's risk perceptions by its investors (Beatty, Ke, \& Petroni, 2002). In contrast, the ownership of private banks is concentrated and their shareholders have a relatively low marginal cost of acquiring and disseminating information (Fan \& Wong, 2002). Since banks operating in Egypt are required to maintain minimum capital regulatory requirements and are diverse in terms of ownership structure, conditions for the accounting discretion practice for income smoothing purposes exists in the Egyptian banking sector. It is also expected that the magnitude of accounting discretion may vary based on ownership structure or bank specialization.

In this study, higher quality of earnings occurs when a bank has (1) persistent components embedded in earnings that are sustainable, (2) high earnings predictability such that past earnings can predict future earnings, (3) low time-series earnings volatility, and (4) less earnings smoothness such that firm's management has not engaged in smoothing practices. However, the effect of discretion of earnings attributes may be positive or negative, depending on whether managers use their discretion efficiently or opportunistically. If they use it efficiently, discretion is expected to improve fundamental earnings attributes. On the other hand, if they use discretion opportunistically, then discretion is expected to impair these attributes. Hence, no prediction is made with respect to the sign of the relation between accounting discretion and earnings attributes. Therefore, the first hypothesis (H1) is stated (in alternative form):

H1: Bank earnings quality is likely to be associated with the extent of accounting discretion.

The hypothesized relations are illustrated in Figure 1. Since four earnings attributes are used to proxy for earnings quality, $\mathrm{H} 1$ is tested separately for each attribute, as follows: persistence, $\mathrm{H} 1_{P R S}$; predictability, $\mathrm{H} 1_{P R D}$; volatility, $\mathrm{H} 1_{V O L}$; and smoothness, $\mathrm{H}_{\text {SMO }}$.

\subsection{Accounting Discretion and Bank Risk-Taking Behavior}

As discussed in section 2.2, accounting information facilitates the prudential regulation and market discipline of banks. This section investigates the impact of accounting discretion through loan loss provisioning on the discipline of bank risk taking behavior. It is assumed that the impact takes place (1) directly between accounting discretion and risk-taking, and/or (2) indirectly, first, through the effects of accounting discretion on earnings attributes and, second, through the effects of these attributes on risk-taking behavior. This section discusses the direct and indirect approaches next. 
Figure 1: Accounting discretion, earnings attributes and risk-taking

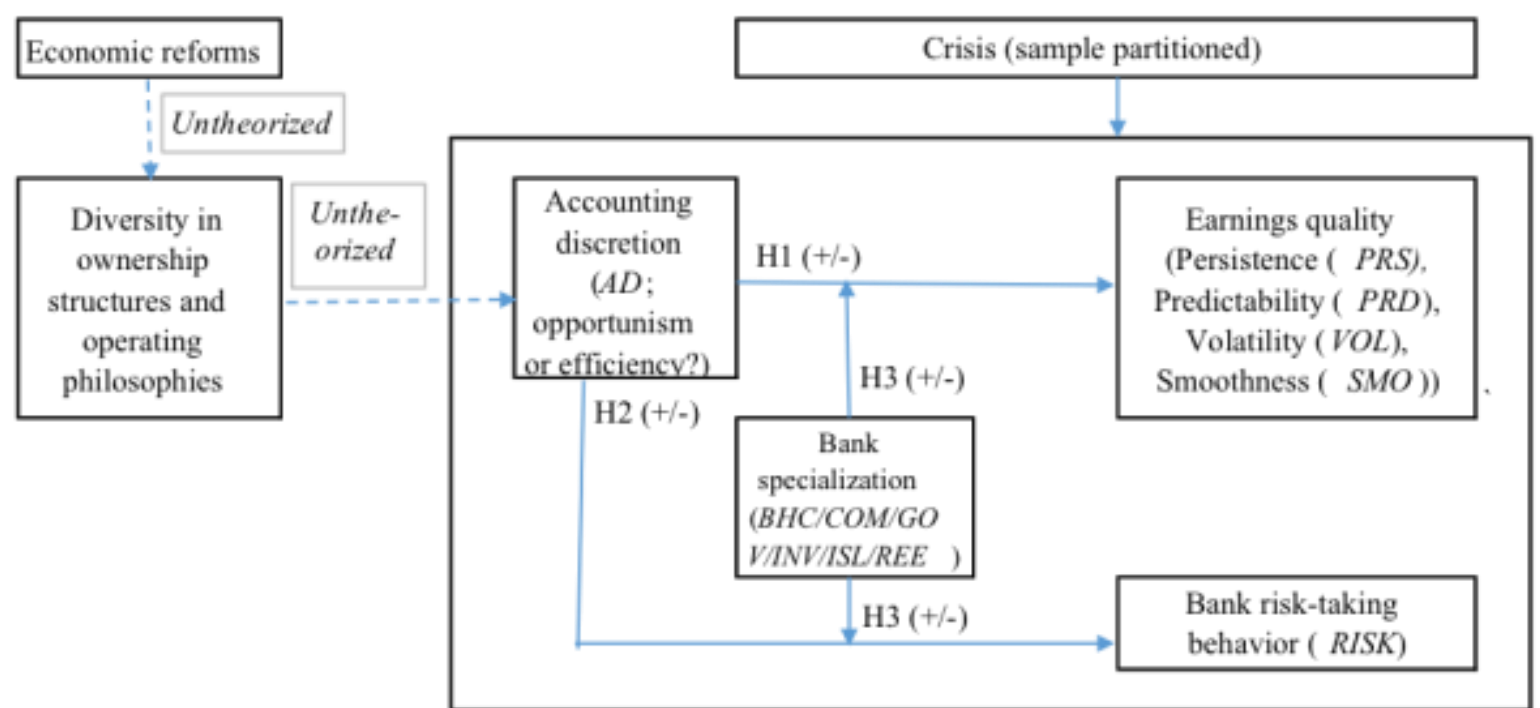

Bushman and Williams (2012) document evidence that banks in countries that allow banks high degree of accounting discretion exhibit higher risk-shifting behavior relative to banks in low discretion countries. They suggest that bank managers use discretion to degrade the transparency of banks and thereby alleviate disciplinary pressure imposed by regulators and investors. These results indicate that in an environment characterized by varying states of accounting discretion, bank managers have the incentive to engage to a large extent in accounting discretion to reduce oversight. In Egypt, the banking environment is characterized by multiple factors that may provide such incentives.

First, following the banking reforms started in 2003, the ownership structure of Egyptian banks has seen major shifts towards non-state institutional investors and foreign owners. The diversity of ownership structures brought a variety of operating philosophies and managerial styles. While all banks are expected to follow the accounting and auditing requirements of the $\mathrm{CBE}$ (based on the Egyptian Accounting Standards), the extent of discretion in choosing accounting methods, policies, and estimates results in varying degrees of conservatism in loss (including LLP) recognition. Second, it is expected that the range of accounting discretion would widen with the existence of different bank types or specializations, e.g., commercial, governmental, real estate, etc. Different bank specializations imply different operating objectives and resource providers who maintain different investment priorities.

Third, despite the existence of minimum regulatory capital requirements set by the CBE and mandated by the Egyptian Banking Act, the CBE provides explicit deposit guarantees to banks operating in Egypt (that depositors will not lose their deposits in case of bank failure). Explicit deposit guarantees by the CBE create incentives for banks to shift risk to the CBE by holding riskier assets that are not backed by proper capital. To counter such incentives, the $\mathrm{CBE}$ and non-depositor clients (e.g., mortgage financing customers) have incentives to monitor and discipline bank risk taking behavior. The reasons discussed above suggest that higher (lower) bank risk-taking is expected to accompany higher (lower) accounting discretion directly. Diversity in ownership structures, differences in bank specializations and the possibility of risk shifting associated with minimum capital requirements provide incentives for this expected direct relation.

The indirect approach is based on the risk of reported information. Extant research provides models positing that the attributes of entity-specific information (e.g., with respect to reflecting changes in the fundamental risk attributes of the underlying loan portfolios) affect the entity's perceived risk and required returns. These models include the incomplete information models, liquidity effect models, and asymmetric information models (Brennan, Chordia, \& Subrahmanyam, 1998). As stated previously, earnings quality is a function of the attributes of financial information, and the less favorable these attributes (e.g., less persistence), the higher the information risk of the reporting entity. Easley and O'Hara (2004) show that in a multi-asset, multi-period setting with informed and uninformed investors, the information risk faced by the uninformed investors is not diversifiable and adds to the entity's total risk. Higher 
information risk from more private information and less precise information leads to higher required returns. Hence, the opportunistic use of discretion by managers is expected to impair the quality of earnings attributes increasing information risk in the process and eventually increasing bank risk-taking activities.

Notwithstanding the above arguments, accounting discretion may be used efficiently to maximize shareholder's long-term wealth. If this is the case, the fundamental earnings attributes will gain in quality and provide better ability to market participants to use the reported information in making sound investment and disciplining decisions. Under this scenario, efficient use of discretion will eventually reduce bank managers' risk-taking behavior. Thus, the second hypothesis (H2) is stated (in an alternative form):

$\mathrm{H} 2$ : Bank risk-taking is likely to be associated with accounting discretion allowed to bank managers.

\subsection{The Role of Bank Specialization in moderating the Effects of Accounting Discretion}

Bank specialization means maximizing the correlations among loan processes of credit holders. Prior research examines the effects of higher specialization in lending and suggests that while higher diversification lowers unexpected losses (Diamond, 1996), higher concentration in lending reduces the loan portfolio risk (Düllmann \& Masschelein, 2007). An empirically strong relation between bank specialization, profitability and market value exists because banks which specialize in certain industries can draw on better industry expertise and monitoring abilities in lowering their loan provision rates and monitoring costs (Hayden, Porath, \& von Westernhagen, 2007; Baele, De Jonghe, \& Vander Vennet, 2007). Therefore, specialized banks are assumed to be better monitored and choose their borrowers more selectively and hence carry lower risk than non-specialized banks on average.

Building on the above literature that argues that bank specialization entails stronger monitoring, it is expected that specialization mitigates the undesirable effects of accounting discretion on earnings attributes and risk-taking behavior. The variance in accounting discretion should be more limited in the case of specialized banks because these banks have a smaller borrower base and hence lower monitoring costs than non-specialized banks. Monitoring by internal auditors, board of directors, external auditors and the CBE should be more effective as lending customers becomes smaller and more homogenous. Therefore, under this interpretation, it is expected that bank specialization mitigates (reduces or reverses) the effect of accounting discretion on earnings attributes and risk-taking behavior.

However, strong ties between banks and their borrowers in individual specializations might lead to failure on the part of their banks to follow due diligence in their credit investigation of repeat borrowers. Furthermore, the small pool for qualified borrowers might pressure banks to relax some of their lending requirements. In these cases, bank managers may exercise further discretion to reduce the impact of nonperforming loans on their profitability, Due to these reasons, specialization may act as a double-edged sword that either mitigates or exacerbates the effects of accounting discretion on earnings attributes. Thus, the third hypotheses (H3) are stated as an extension to the first two hypotheses (in alternative form):

H3: Bank specialization is likely to exacerbate or mitigate the effects of accounting discretion on earnings attributes and risk-taking.

Similar to the first hypothesis, H3 is tested separately for each earnings attribute and bank risk-taking. Each sub-hypothesis is denoted as follows: persistence, $\mathrm{H} 3_{P R S}$; predictability, $\mathrm{H} 3_{P R D}$; volatility, $\mathrm{H} 3_{V O L}$; smoothness, $\mathrm{H} 3_{S M O}$; and risk-taking, $\mathrm{H} 3_{\text {RISK }}$.

\section{Sample and Variable Definition}

In this section, the sample selection procedure is introduced and the variable definitions are discussed. The analysis is conducted separately for the non-crisis and the crisis periods because the extreme events that took place during the crisis years might disrupt the patterns characterizing each bank in the non-crisis period

\subsection{Sample Selection}

The sample period of the study spans 2000-2015. All bank financial statement data is drawn from Bankscope. Macroeconomic (inflation and gross domestic product) variables were derived from the World Development Indicators Database. Detailed information concerning variable construction and data sources are included in Appendix A. To be included in the sample a bank is required to have all necessary bank-level data spanning a period of at least three years. Each bank is also required to have more than 200 million Egyptian Pounds (US\$ 22,727,272.73) in total assets. Financial data is winsorized at the 1 and 99 percentiles. These general requirements generate a sample of 705 potential bank-quarter observations from 46 different banks that operated in Egypt during the sample period. The lack of availability of financial data for some banks results in further loss of 71 observations yielding a final sample of 634 bank-quarters. 
Multiple studies indicate that bank financial information was aggregately affected by the financial crisis of 2008-2009 (Cohen et al., 2014; Huizinga \& Laeven, 2009). The Egyptian banking system has undergone turbulent economic circumstances that severely affected its liquidity and competitiveness. Since these crises years (global financial crisis 2008-2009 and local unrest in 2011 and 2013) are expected to immensely increase uncertainty regarding the future of the sample banks, the sample is partitioned into two subsamples representing crisis (2008-2009, 2011, and 2013; 188 bank-quarters) and non-crisis periods (all other years; 446 bank-quarters).

\subsection{Summary Statistics}

Table 1, Panel A, presents summary statistics for the sample of 46 banks over the 2000-2015 period in thousands of U.S. dollars. The statistics suggest that a wide variation exists between the sample banks with respect to their economic characteristics. Mean total assets exceeds $\$ 3$ billion and the median is $\$ 1.283$ billion indicating the effects of larger banks. The largest bank has close to $\$ 52$ billion in assets while the smallest has almost $\$ 26$ million. The standard deviation is very large ( $\$ 5.6$ billion) indicating wide variation in the sample in terms of size. This large variation suggests that banks are different in terms of their operating resources, customer base and regulatory requirements. As fractions of total assets, the variation is also apparent in the disparity between the minimum and maximum LLP (-0.424 and 23.282 percent, respectively), loans (0.022 and 93.871 percent, respectively), net income (-24.439 and 15.746 percent, respectively), and total equity (12.567 and 86.124 percent, respectively). The standard deviation as a percentage of total assets is highest for total equity (10.036 percent) and total loans (17.758 percent), suggesting different practices affecting capital adequacy and credit/loan management.

The wide variations between the banks is attributed to the fact that some banks are established by large international financial institutions (e.g., HSBC, Barclays Banks) while others have started and continued as local banks serving a niche of the banking market (e.g., Principal Bank for Development and Agricultural Credit). Untabulated results show that the average ownership share of foreign-owned banks increased steadily from 24.48 percent in 2003 (the year of passing the Egyptian Banking Act) to 45.69 percent in 2015. Institutional investors have also experienced an increase from 80.39 percent to 85.08 percent in 2015 . Similarly, the average share of the largest investor increased from 48.71 percent in 2003 to 68.87 percent in 2015. These statistics indicate that the banking sector has seen increasing consolidation of ownership towards institutional and foreign investors. Also, the banks differ with respect to the years they have served the Egyptian market (e.g., National bank of Egypt has over 100 years of experience and investment accumulation versus Piraeus Bank which is a recent foreign entrant into the market). It follows from the variation in the above statistics that wide variation is to be expected in the earnings attributes, risk and accounting discretion variables as well.

Table 1. Descriptive statistics and correlations, 2000-2015

Panel A: Summary statistics

\begin{tabular}{lllllllllll}
\hline Bank characteristics & Min. & $\%$ & Mean & $\%$ & SD & $\%$ & Median & $\%$ & Max. & $\%$ \\
\hline Loan loss provisions & $-125,556.8$ & -0.4 & $21,421.6$ & 0.9 & $71,571.1$ & 1.5 & $5,431.4$ & 0.6 & $899,284.1$ & 23.3 \\
Total loans & 56.8 & 0.0 & $1,122,538.9$ & 43.9 & $1,741,455.9$ & 17.8 & $480,568.2$ & 42.4 & $13,221,511.4$ & 93.9 \\
Non-performing loans & 556.8 & 0.1 & $169,561.7$ & 5.8 & $396,411.3$ & 5.2 & $45,636.4$ & 4.7 & $2,689,795.5$ & 32.3 \\
Net income & $-134,954.5$ & -24.4 & $27,128.7$ & 1.0 & $58,328.5$ & 2.2 & $10,829.5$ & 0.9 & $425,886.4$ & 15.7 \\
Total equity & 102.3 & 12.6 & $384,675.0$ & 11.5 & $441,771.4$ & 10.0 & $217,784.1$ & 9.1 & $2,489,545.5$ & 86.1 \\
Total Assets & $25,909.1$ & & $3,002,021.9$ & $5,636,790.1$ & & $1,283,193.2$ & & $51,877,261.4$ & \\
\hline
\end{tabular}

Panel A presents summary statistics (and percentage of total assets in parentheses) for the sample of 46 Egyptian banks in thousands of U.S. Dollars (1 U.S. Dollar $=8.87$ Egyptian Pound as of June 23, 2016) 
Panel B: Descriptive statistics for the study variables

\begin{tabular}{|c|c|c|c|c|c|c|c|c|}
\hline Variables & $\mathrm{NC} 0 / \mathrm{C} 1$ & Min. & $1^{\text {st }}$ pct. & Mean & Median & SD & $99^{\text {th }}$ pct. & Max. \\
\hline \multirow[t]{2}{*}{$A D$} & 0 & -0.023 & -0.021 & 0.003 & 0.000 & 0.011 & 0.055 & 0.060 \\
\hline & 1 & -0.005 & -0.005 & 0.000 & 0.000 & 0.002 & 0.009 & 0.009 \\
\hline \multirow[t]{2}{*}{$P R S$} & 0 & -0.320 & -0.202 & 0.016 & 0.010 & 0.081 & 0.699 & 0.730 \\
\hline & 1 & -0.288 & -0.288 & 0.018 & 0.010 & 0.128 & 0.788 & 0.960 \\
\hline \multirow[t]{2}{*}{$P R D$} & 0 & 0.000 & 0.000 & 0.561 & 0.312 & 1.049 & 4.593 & 10.752 \\
\hline & 1 & 0.000 & 0.000 & 0.619 & 0.381 & 0.752 & 4.142 & 4.322 \\
\hline \multirow[t]{2}{*}{$V O L$} & 0 & 0.000 & 0.000 & 0.006 & 0.004 & 0.011 & 0.049 & 0.162 \\
\hline & 1 & 0.000 & 0.000 & 0.006 & 0.004 & 0.008 & 0.054 & 0.054 \\
\hline \multirow[t]{2}{*}{$S M O$} & 0 & 0.004 & 0.004 & 0.092 & 0.051 & 0.163 & 0.922 & 0.922 \\
\hline & 1 & 0.059 & 0.059 & 0.232 & 0.150 & 0.250 & 1.048 & 1.048 \\
\hline \multirow[t]{2}{*}{ RISK } & 0 & 0.484 & 1.099 & 3.250 & 3.212 & 0.880 & 5.629 & 5.875 \\
\hline & 1 & 0.780 & 0.805 & 3.234 & 3.247 & 0.848 & 5.149 & 5.163 \\
\hline \multirow[t]{2}{*}{ PROV } & 0 & -0.004 & -0.003 & 0.010 & 0.007 & 0.017 & 0.068 & 0.233 \\
\hline & 1 & -0.004 & -0.004 & 0.006 & 0.004 & 0.009 & 0.055 & 0.058 \\
\hline \multirow[t]{2}{*}{$S Z E$} & 0 & 0.824 & 1.211 & 4.515 & 4.559 & 1.349 & 7.959 & 8.426 \\
\hline & 1 & 3.154 & 3.207 & 5.217 & 5.081 & 1.011 & 8.149 & 8.205 \\
\hline \multirow[t]{2}{*}{$N P L$} & 0 & 0.005 & 0.005 & 0.127 & 0.083 & 0.123 & 0.592 & 0.594 \\
\hline & 1 & 0.006 & 0.006 & 0.124 & 0.079 & 0.131 & 0.467 & 0.542 \\
\hline \multirow[t]{2}{*}{$L L R$} & 0 & 0.008 & 0.009 & 0.204 & 0.149 & 0.178 & 0.930 & 0.964 \\
\hline & 1 & 0.010 & 0.011 & 0.172 & 0.109 & 0.177 & 0.860 & 0.885 \\
\hline \multirow[t]{2}{*}{$L O A N$} & 0 & 0.984 & 0.207 & 3.614 & 3.536 & 1.452 & 6.674 & 7.059 \\
\hline & 1 & 1.560 & 1.670 & 4.238 & 4.069 & 1.024 & 6.900 & 6.973 \\
\hline \multirow[t]{2}{*}{$I N C$} & 0 & -8.160 & -4.006 & 1.296 & 0.840 & 2.265 & 11.095 & 19.620 \\
\hline & 1 & -4.870 & -4.870 & 1.410 & 1.655 & 2.054 & 4.982 & 6.690 \\
\hline \multirow[t]{2}{*}{$L G R$} & 0 & -0.384 & -0.278 & 0.871 & 0.389 & 1.081 & 5.588 & 5.662 \\
\hline & 1 & -0.322 & -0.322 & 0.464 & 0.225 & 0.740 & 3.893 & 4.502 \\
\hline \multirow[t]{2}{*}{$N P C$} & 0 & -0.183 & -0.183 & -0.001 & -0.001 & 0.046 & 0.103 & 0.118 \\
\hline & 1 & -0.182 & -0.182 & -0.007 & -0.008 & 0.069 & 0.319 & 0.336 \\
\hline \multirow[t]{2}{*}{$E B L L P$} & 0 & -0.023 & -0.012 & 0.021 & 0.019 & 0.018 & 0.089 & 0.205 \\
\hline & 1 & -0.018 & -0.017 & 0.021 & 0.021 & 0.015 & 0.108 & 0.115 \\
\hline \multirow[t]{2}{*}{$A D Q$} & 0 & 0.139 & 0.477 & 0.889 & 0.914 & 0.097 & 0.975 & 1.126 \\
\hline & 1 & 0.183 & 0.193 & 0.876 & 0.894 & 0.109 & 1.006 & 1.015 \\
\hline \multirow[t]{2}{*}{$R O A$} & 0 & -0.244 & -0.050 & 0.009 & 0.008 & 0.022 & 0.070 & 0.157 \\
\hline & 1 & -0.082 & -0.071 & 0.010 & 0.012 & 0.020 & 0.086 & 0.094 \\
\hline \multirow[t]{2}{*}{$C P I$} & 0 & 0.045 & 0.045 & 0.082 & 0.085 & 0.028 & 0.113 & 0.113 \\
\hline & 1 & 0.101 & 0.101 & 0.134 & 0.118 & 0.035 & 0.183 & 0.183 \\
\hline \multirow[t]{2}{*}{$G P G$} & 0 & 0.032 & 0.032 & 0.052 & 0.049 & 0.014 & 0.071 & 0.071 \\
\hline & 1 & 0.018 & 0.018 & 0.046 & 0.047 & 0.022 & 0.072 & 0.072 \\
\hline
\end{tabular}

Panel B presents descriptive statistics for the study variables by crisis period for the sample of 46 Egyptian banks. Number of observations for the non-crisis (crisis) period is 464 (188) bank-quarters. Variable definitions are as presented in Appendix A. 
Panel C: Study variables across bank specializations, 2000-2015

\begin{tabular}{|c|c|c|c|c|c|c|c|c|c|c|c|c|c|c|c|}
\hline \multirow[b]{2}{*}{ Variable } & \multirow[b]{2}{*}{ Period } & \multicolumn{2}{|c|}{ BHC (13) } & \multicolumn{2}{|c|}{ Commercial (429) } & \multicolumn{2}{|c|}{ Governmental (65) } & \multicolumn{2}{|c|}{ Investment (39) } & \multicolumn{2}{|c|}{ Islamic (39) } & \multicolumn{2}{|c|}{ Real Estute (13) } & \multicolumn{2}{|c|}{ Total (634) } \\
\hline & & Mean & SD & Mean & $\mathrm{SD}$ & Mean & SD & Mezan & SD & Mean & $\mathrm{SD}$ & Mean & SD & Mean & SD \\
\hline \multirow[t]{2}{*}{ PRS } & 0 & 1.360 & 0.770 & 1.540 & 7.200 & 0.700 & 1.710 & 3.200 & 1.110 & 0.530 & 1.320 & -1.630 & 7,690 & 0.016 & 0.081 \\
\hline & 1 & 0.540 & 0.480 & 3.080 & 15.890 & 0.850 & 0.350 & 0.560 & 0.510 & -3.810 & 11.100 & 1.170 & 0.150 & 0.018 & 0.128 \\
\hline \multirow[t]{2}{*}{$P R D$} & 0 & 3.664 & 4.070 & 0.467 & 0.585 & 0.589 & 0.703 & 0.679 & 0.985 & 0.339 & 0.389 & 0.914 & 1.104 & 0.561 & 1,049 \\
\hline & 1 & 3.689 & 4.006 & 0.536 & 0.577 & 0.622 & 0.711 & 0.828 & 0.983 & 0.422 & 0.388 & 1.019 & 1.222 & 0.619 & 0.752 \\
\hline \multirow[t]{2}{*}{$V O L$} & 0 & 0.071 & 0.068 & 0.006 & 0.006 & 0.008 & 0.006 & 0.010 & 0.007 & 0.004 & 0.002 & 0.006 & 0.003 & 0.006 & 0.004 \\
\hline & 1 & 0.031 & 0.018 & $0.00 ?$ & $0.00 ?$ & 0.008 & 0.006 & 0.009 & 0.007 & 0.006 & 0.003 & 0.004 & 0.003 & 0.006 & 0.004 \\
\hline \multirow[t]{2}{*}{ SWO } & 0 & 0.045 & 0.006 & 0.051 & 0.044 & 0.033 & 0.085 & 0.004 & 0.056 & 0.470 & 0.258 & 0.922 & 0.031 & 0.092 & 0.163 \\
\hline & 1 & 0.059 & 0.007 & 0.150 & 0.132 & 0.223 & 0.340 & 0.130 & 0.087 & 1.048 & 0.471 & 0.990 & 0.028 & 0.232 & 0.250 \\
\hline \multirow[t]{2}{*}{ RISA } & 0 & 2.525 & 1.201 & 3.296 & 0.848 & 3.545 & 0.904 & 2.637 & 0.668 & 3.097 & 0.592 & 1.996 & 0.977 & 3.250 & 0.880 \\
\hline & 1 & 2.949 & 0.741 & 3.266 & 0.905 & 3.429 & 0.581 & 3.128 & 0.679 & 2.905 & 0.496 & 1.197 & 0.963 & 3.234 & 0.848 \\
\hline$A D$ & 0 & -0.130 & 0.475 & 2.583 & 11.583 & 0.027 & 2.476 & -1.627 & 6.213 & 4.473 & 11.271 & 34.343 & 17.836 & 2.687 & 11.327 \\
\hline & 1 & -0.235 & 1.295 & 0.374 & 2.286 & -1.169 & 3399 & 1.158 & 1.981 & -0.546 & 1.116 & 32.314 & 14.433 & 0.066 & 2.428 \\
\hline \multirow[t]{2}{*}{ PROV } & 0 & 0.002 & 0.003 & 0.011 & 0.019 & 0.009 & 0.009 & 0.010 & 0.005 & 0.006 & 0.005 & 0.006 & 0.004 & 0.010 & 0.017 \\
\hline & 1 & 0.003 & 0,005 & 0.007 & 0.1010 & 0.006 & 0.007 & 0.008 & 0.006 & 0.007 & 0.010 & 0.0063 & 0.001 & 0.006 & 0.009 \\
\hline \multirow[t]{2}{*}{ SIZE } & 0 & 6.813 & 1.341 & 6.128 & 1.409 & 5.499 & 0.828 & 4.035 & 1.712 & 6.188 & 0.899 & 6.688 & 0.225 & 4.559 & 1.349 \\
\hline & 1 & 7.042 & 0.997 & 6.887 & 1.034 & 5.072 & 0.543 & 5.101 & 1.574 & 6.848 & 0.525 & 6.965 & 0.077 & 5.081 & 1.011 \\
\hline \multirow[t]{2}{*}{$N P L$} & 0 & 0.039 & 0,005 & 0.139 & 0.130 & 0.076 & 0.049 & 0.038 & 0.008 & 0.159 & 0.142 & 12.635 & 0.074 & 0.127 & 0.123 \\
\hline & 1 & 0.293 & 0.293 & 0.122 & 0.127 & 0.063 & 0.070 & 0.027 & 0.005 & 0.258 & 0.184 & 10.305 & 0.061 & 0.124 & 0.131 \\
\hline \multirow[t]{2}{*}{$L L R$} & 0 & 0.017 & 0.017 & 0.221 & 0,177 & 0.128 & 0.103 & 0.135 & 0.120 & 0.243 & 0.274 & 0.055 & 0,018 & 0.204 & 0,178 \\
\hline & 1 & 0.017 & 0.017 & 0.190 & 0.188 & 0.088 & 0.059 & 0.184 & 0.183 & 0.222 & 0.196 & 0.020 & 0.004 & 0.172 & 0.177 \\
\hline \multirow[t]{2}{*}{$\angle O A N$} & 0 & 5.167 & 1.527 & 5.172 & 1387 & 3.966 & 0.737 & 3.598 & 1.485 & 4.704 & 2.757 & 6.491 & 0.171 & 3.614 & 1.452 \\
\hline & 1 & 4.877 & 1.895 & 5.861 & 1.031 & 3.486 & 0.588 & 3.375 & 1.623 & 5.693 & 0.624 & 6.474 & 0.070 & 4.238 & 1.024 \\
\hline \multirow[t]{2}{*}{$I N C$} & 0 & 2.903 & 2.408 & 1.042 & L.566 & 2.070 & 2.320 & 1.753 & 2.233 & 1.069 & 1.024 & -.795 & 1.380 & 1.296 & 2.265 \\
\hline & 1 & 2.155 & 2.454 & 1.303 & 1.858 & 2.514 & 2.083 & 1.628 & 1.381 & 1.273 & 1.397 & -4.345 & .742 & 1,410 & 2,054 \\
\hline \multirow[t]{2}{*}{$\angle G R O$} & 0 & 2.958 & 2.023 & 0.872 & 1.109 & 0.454 & 0.649 & 0.966 & 0.616 & 1.031 & 1.472 & 2.042 & 0.252 & 0.871 & 1.081 \\
\hline & 1 & 1.676 & 1. .051 & 0.339 & 0.418 & 0.552 & 1.264 & 1.015 & 1.060 & 0.213 & 0.353 & 0.557 & 0.197 & 0.464 & 0.740 \\
\hline \multirow[t]{2}{*}{$A D Q$} & 0 & 0.421 & 0.298 & 1.096 & 0.051 & 0.204 & 0.148 & 0.037 & 0.045 & 0.054 & 0.016 & 0.041 & 0.017 & 0.889 & 0.097 \\
\hline & 1 & 0.495 & 0.354 & 1.100 & 0.040 & 0.201 & 0.108 & 0.119 & 0.035 & 0.060 & 0.007 & 0.011 & 0.037 & 0.876 & 0.109 \\
\hline \multirow[t]{2}{*}{ NPLC } & 0 & 0.003 & 0.020 & -0.001 & 0.050 & 0.006 & 0.033 & 0.011 & 0.003 & -0.026 & 0.013 & 0.003 & 0.001 & -0.001 & 0,046 \\
\hline & 1 & 0.040 & 0.230 & -0.017 & 0.046 & $=0.008$ & 0.042 & -0.0003 & 0.033 & 0.071 & 0.177 & 0.004 & .0 .012 & $-0,008$ & 0.069 \\
\hline \multirow[t]{2}{*}{ EBLLP } & 0 & 0.076 & 0.079 & 0.019 & 0.013 & 0.030 & 0.012 & 0.023 & 0.016 & 0.014 & 0.007 & 0.007 & 0.004 & 0,021 & 0.018 \\
\hline & 1 & 0.044 & 0.054 & 0.020 & 0.012 & 0.025 & 0.007 & 0,024 & 0.010 & 0.020 & 0.006 & -0.006 & -0.009 & 0,021 & 0.015 \\
\hline
\end{tabular}

Panel C presents mean and standard deviations for study variables by specialization and period (non-crisis $=0$, crisis $=1)$ for the sample of 46 Egyptian banks.

Panel D: Pearson (top triangle) and Spearman (bottom triangle) correlations, 2000-2015

\begin{tabular}{lrrrrrr}
\hline \multicolumn{7}{c}{ Non-Crisis period } \\
\hline Variables & $A D$ & $P R S$ & $P R D$ & $V O L$ & $S M O$ & $R I S K$ \\
$A D$ & 1.000 & 0.034 & -0.067 & -0.124 & $0.239^{* * *}$ & $-0.143^{*}$ \\
$P R S$ & $-0.239^{* *}$ & 1.000 & 0.088 & 0.022 & -0.094 & -0.001 \\
$P R D$ & $-0.136^{*}$ & 0.067 & 1.000 & $0.651^{* * *}$ & -0.011 & $-0.202^{* * *}$ \\
$V O L$ & -0.113 & 0.015 & $0.226^{* * *}$ & 1.000 & -0.054 & $-0.366^{* * *}$ \\
$S M O$ & $0.135^{*}$ & -0.067 & -0.074 & $-0.155^{* * *}$ & 1.000 & $-0.192^{* * *}$ \\
RISK & -0.053 & -0.011 & $-0.191^{* * *}$ & $-0.577^{* * *}$ & -0.040 & 1.000
\end{tabular}

\begin{tabular}{lrrrrrr}
\hline \multicolumn{7}{c}{ Crisis period } \\
\hline Variables & $A D$ & $P R S$ & $P R D$ & $V O L$ & $S M O$ & $R I S K$ \\
$A D$ & 1.000 & $-0.628^{* * *}$ & 0.053 & -0.215 & 0.047 & -0.010 \\
$P R S$ & 0.239 & 1.000 & -0.041 & $0.273^{* *}$ & -0.124 & -0.154 \\
$P R D$ & 0.026 & $-0.338^{* * *}$ & 1.000 & $0.408^{* * *}$ & -0.021 & $-0.178^{* *}$ \\
$V O L$ & -0.201 & $-0.223^{*}$ & $0.256^{* * *}$ & 1.000 & -0.118 & $-0.522^{* * *}$ \\
$S M O$ & -0.102 & 0.063 & -0.067 & -0.052 & 1.000 & $-0.153^{*}$ \\
$R I S K$ & -0.042 & -0.009 & $-0.211^{* * *}$ & $-0.659^{* * *}$ & -0.062 & 1.000 \\
\hline
\end{tabular}

***,**,* indicates significance at the $0.01,0.05$ and 0.10 level respectively. Variable definitions are as presented in Appendix A.

\subsection{Estimating Bank-level Discretion in Loan Loss Provisioning Practices}

Current accounting procedures for loan loss provisioning under the IFRS-based Egyptian Accounting Standards are based on the incurred loss framework. According to this framework, a provision for loan losses is recognized only after loss impairment events have already occurred prior to the financial reporting date that are likely to result in 
non-payment of loans in the future (Bushman \& Williams, 2012). Under this model, the regulatory capital exists to absorb potential losses that are not absorbed by the loan loss reserve account, which accumulates net LLPs in the statement of financial position (Basel Committee on Banking Supervision, 1991; Wall \& Koch, 2000).

The first step in the analysis is to empirically derive estimates of accounting discretion practiced by each bank $i$ in quarter $t$. In this study, the approach suggested in Beatty et al. (2002) to calculate the discretionary LLP is used. The model estimates abnormal (discretionary) LLP as the error of a regression of LLP on a number of determining factors, specifically, bank size, nonperforming loans, loan loss reserves, and total loans outstanding (Note 7). The model, estimated in the period 2000-2015, is shown as Equation 1:

$$
P R O V_{i t}=\beta_{0}+\beta_{1} S I Z E_{i t}+\beta_{2} N P L_{i t}+\beta_{3} L L R_{i t}+\beta_{4} L O A N_{i t}+\varepsilon_{\text {it }}
$$

Where all variables are as defined in Appendix $\mathrm{A}$ and $\varepsilon_{i t}$ is the error term. The fitted values of $P R O V$ in equation 1 represents normal LLP based on the factors identified in prior literature as determinants of LLP, and therefore, the residual (unexplained portion) of the regression represents the discretionary component of LLP in raw form. This residual is then transformed by multiplying it by total loans divided by total assets in order to match the basis used in the following models. The transformed variable is the measure of discretionary LLP used in the remaining analyses of the paper as representing accounting discretion $(A D)$, which is the explanatory variable of interest in this study.

Note that Equation 1 above are estimated separately for the non-crisis and crisis periods, so the residual represents the economic realities during these two disparate periods. Higher levels of $A D$ imply higher managerial manipulation of LLPs, and therefore higher $A D$ should be associated with lower earnings quality. All variables are defined in Appendix A. All bank-specific variables are winsorized at the 1 and 99 percentiles and standard errors are clustered at the bank level.

Table 2, Panel A, shows the results of estimating Equation 1 across the non-crisis and crisis period. The model fit statistics indicate that the model reliably fits the data for both periods with highly significant $f$-statistics and adjusted $R^{2}$ of 21.7 percent and 15.2 percent, respectively. Consistent with prior research by Laeven and Majnoni (2003), bank size is significantly positively related to LLP, while loan loss reserves and loans outstanding are significantly negatively associated with LLP across both periods. These results indicate that on average the provisioning activities of Egyptian banks vary inversely with their size, potentially because smaller banks are more sensitive to loan losses and hence provision more to maintain their compliance with minimum capital requirements. The positive relations with loan loss reserves and loans indicate that banks provision more as their lending activities increase and to build up their loan loss reserves to maintain capital adequacy. The residuals from Equation 1 form the basis for $A D$ calculations.

Table 2, Panel B, examines the time series properties of $A D$ (accounting discretion), and presents the results of regressing cotemporaneous discretion on its one-, two-, and three-year lagged values. The table shows significantly positive serial correlation between $A D$ and its one-year lagged values in the non-crisis (0.419) and crisis (0.228) periods. But, for the longer-term, the relation reverses and becomes significantly negative between $A D$ and its two-year lagged values for the crisis period. The longer-term relations are insignificant in the crisis period. This pattern of positive short-term relations and negative long-term relations has been documented in prior research in banking and non-banking (e.g., Dechow and Dichev, 2002) studies and suggests that discretionary contributions to earnings due to unexplained LLP tends to reverse within the second and third years, but in the Egyptian case the reversal takes place mostly within the second year. 
Table 2. Estimation and analysis of accounting discretion through loan loss provisions

Panel A: Estimating accounting discretion through loan loss provisions

\begin{tabular}{lcr}
\hline \multicolumn{3}{c}{ Dependent variable: PROV } \\
\hline Variables & \multicolumn{1}{c}{ Non-Crisis } & \multicolumn{1}{c}{ Crisis } \\
\hline Intercept & $-0.007(-0.5405)$ & $0.0118^{*}(1.7109)$ \\
$S Z E$ & $-0.0068^{* * *}(-3.0114)$ & $-0.0027^{* * *}(-3.0632)$ \\
$N P L$ & $-0.0047(-0.5062)$ & $-0.0041(-0.6811)$ \\
$L L R$ & $0.0291^{* * *}(3.1511)$ & $0.0174^{* * *}(3.4486)$ \\
$L O A N$ & $0.0078^{* * *}(3.2695)$ & $0.0023^{* * *}(2.7125)$ \\
\hline & Model statistics & \\
\hline -statistic & $4.0483^{* * *}$ & $4.7510^{* * *}$ \\
Adj. $R^{2}$ & 0.217 & 0.152 \\
Observations (bank- qtrs) & 446 & 188 \\
\hline
\end{tabular}

$* * *, * *, *$ indicates significance at the $0.01,0.05$ and 0.10 level respectively. Variable definitions are as presented in Appendix A. Panel A shows the OLS regression coefficient estimates ( $t$-statistics) of Equation (1).

Panel B: Time series behavior of accounting discretion

\begin{tabular}{lrr}
\hline \multicolumn{3}{c}{ Dependent variable: $A D$} \\
\hline Variables (lag year) & \multicolumn{1}{c}{ Non-Crisis } & \multicolumn{1}{c}{ Crisis } \\
\hline Intercept & $0.001^{* * *}(3.379)$ & $0.001(0.070)$ \\
$A D(-1)$ & $0.419^{* * *}(7.823)$ & $0.228^{* * *}(2.974)$ \\
$A D(-2)$ & $-0.154^{* * *}(-2.682)$ & $0.074(0.911)$ \\
$A D(-3)$ & 0.020 & $0.016(0.855)$ \\
\hline \multicolumn{3}{c}{ Model statistics } \\
\hline$F$-statistic & $20.602^{* * *}$ \\
Adj. $R^{2}$ & 0.143 & $4.105^{* * *}$ \\
Observations (bank- qtrs) & 446 & 0.048 \\
\hline
\end{tabular}

$* * *, * *, *$ indicates significance at the $0.01,0.05$ and 0.10 level respectively. Variable definitions are as presented in Appendix A. Panel B presents the OLS regression coefficient estimates (t-statistics) of a model regressing accounting discretion $(A D)$ on its own one-, two-, and three-year lagged values, respectively) separately for the non-crisis and the crisis periods.

This time-series dependence using Egyptian bank data implies that (1) bank managers do not consistently use unbiased estimates of future loan losses to determine proper LLP levels, (2) they take a strategic view when setting the LLP levels to project a favorable image of the bank's financial condition, and (3) the pattern of reversals reveal efforts of managers to undo prior accrual overstatements of reported earnings (Cohen et al., 2014). Results in this study suggests that this serial correlation does not reliably exist during crisis periods, potentially because of the disruption of the usual environment for business decision-making, leading managers to take different or unexpected courses of action to improve business performance. The insignificant longer-term results during crisis period could be the subject for future research on bank managers' responses to poor business performance during turbulent periods. Next, the procedure for the estimation of earnings attributes is discussed.

\subsection{Earnings Attributes and Bank Risk-Taking Measures}

In this section, the procedures for the estimation of the four earnings attributes (persistence, predictability, volatility and smoothness) used in this study to proxy for earnings quality are discussed.

\subsubsection{Earnings Persistence}

This study adapts the methodology followed widely by prior research (Cohen et al., 2014) in measuring earnings persistence. Prior studies estimate persistence as the slope coefficient estimate, $\alpha_{1, \mathrm{i}}$, from an autoregressive model of order one $(\mathrm{ARl})$ for pre-tax income scaled by lagged total assets $\left(I N C_{i t}\right)$ in year $t$, as shown in Equation 2 :

$$
I N C_{i t}=\alpha_{0, i}+\alpha_{1, i} I N C_{i t-1}+\mu_{i t}
$$

Where the variables are as defined in Appendix A and $\mu_{i t}$ is the error term. 


\subsubsection{Earnings Predictability, Volatility and Smoothness}

Prior literature estimates earnings predictability $(P R D)$ as the variance of unexpected earnings from Equation 2a, with higher variance representing lower predictability (Francis, Lafond, Olsson, \& Schipper, 2004). As will be discussed in Section 4.1, this study uses an adapted version of Equation 2 (Equation $2 *$ ) to derive the measure of earnings predictability using the bank- and quarter-specific ARl model. The variable $P R D$ is estimated as the standard deviation of the residuals $\left(\mu_{\mathrm{it}}\right)$ from Equation $2^{*}, P R D=\sqrt{ }\left(\sigma^{2}\left(\mu_{i t}\right)\right)$. Large (small) values of $P R D$ indicate less (more) predictable earnings and hence lower (higher) quality.

As for earnings volatility, this study follows prior literature in estimating earnings volatility as the coefficient of variation of the bank's return on average assets as the variance of unexpected earnings, with higher values representing higher volatility (Antle \& Smith, 1986). Large (small) values of VOL indicate more (less) volatile earnings and hence lower (higher) quality.

As for earnings smoothness, this study follows Bushman and Williams (2012) in measuring smoothness through LLP $(S M O)$ as the coefficient on the earnings before LLP (PROV) from the following regression model, which is estimated using OLS:

$$
\begin{aligned}
\operatorname{PROV}_{i t}= & \rho_{0, i}+\rho_{1, i} E B L L P_{i t}+\rho_{2, i} N P C_{i t}+\rho_{3, i} N C O_{i t}+\rho_{14, i} L L R_{i t-1}+\rho_{5, i} A D Q_{i t-1} \\
& +\rho_{6, i} L O A N_{i t-1}+\rho_{7, i} S Z E_{i t-1}+\rho_{8, i} L G R_{i t}+\rho_{9, i} G P G_{i t}+\delta_{i t}
\end{aligned}
$$

Where the variables are as defined in Appendix A and $\delta_{i t}$ is the error term. Under the incurred loss model (Note 8), earnings should not explain contemporaneous provisioning behavior, and therefore larger values of $S M O$ indicate higher levels of earnings smoothness activities and lower (higher) earnings quality. The change in non-performing loans $(N P C)$ and net charge-offs $(N C O)$ are included to capture observed changes in portfolio performance and collectability. All other control variables are as described above.

\subsubsection{Bank Risk Taking}

This study follows prior literature in measuring bank risk as the natural logarithm of the $z$-score of each bank (Laeven \& Levine, 2008), which measures the distance from the state of insolvency, defined as the point where losses exceed equity. More specifically, a bank's $z$-score is measured as the sum of the return on assets and the capital-asset ratio divided by the standard deviation of asset returns. Thus, $z$ indicates the standard deviations that a bank's ROA has as a "safety" before equity is depleted. A higher $z$-score indicates that the bank is more stable.

\subsubsection{Control Variables}

To control for bank characteristics suggested by prior research to affect earnings attributes and risk (Bharath, Sunder, \& Sunder, 2008; Bushman \& Williams, 2012; Francis, Hasan, Koetter, \& Wu, 2012; Graham, Li, \& Qiu, 2008), additional variables are included in Equation 2a. Current period real loan growth $(L G R)$ is included to control for the increase in loan provisioning related to normal increase in outstanding loans (Liu \& Ryan, 2006), which is also related to risk of the loan portfolio. Loan loss reserves $(L L R)$ is included to capture issues with loan collectability and hence the risk of the loan portfolio (e.g., Foos, Norden, \& Weber, 2010). Macroeconomic events affect collectability of loans. Therefore, the GDP growth per capita $(G P G)$ and inflation $(C P I)$ are included to control for these events. In addition, capital adequacy $(A D Q)$ and the size of the bank $(S Z E)$ to control for the negative effects of size and asset mix on information asymmetry. Variable definitions are as presented in Appendix A.

\subsection{Descriptive Statistics and Correlations}

Table 1, Panel B, presents the descriptive statistics on the study variables. Accounting discretion, $A D$, in the non-crisis (crisis) period ranges from the $1^{\text {st }}$ percentile value of $-0.021(-0.005)$ percent to a $99^{\text {th }}$ percentile value of $0.055(0.009)$ percent of assets. The wide range suggests that accounting discretion through LLP is heavily practiced. Standard deviation for the non-crisis (crisis) period is $0.011(0.002)$ percent of assets. In comparison, the standard deviation of return on assets $(R O A)$ is $0.022(0.020)$ percent of assets for the non-crisis (crisis) period, suggesting that a sizable portion of the variation in reported bank performance is due to managerial discretion. Accounting discretion for the crisis period is more inclined towards reducing LLP as shown by the mean and minimum values of $A D$ during the crisis period relative to the non-crisis period.

Egyptian banks fall into one of six Bankscope bank specialization categories according to their primary area of specialization: bank holding company $(B H C)$, commercial $(C O M)$, governmental $(G O V)$, investment $(I N V)$, Islamic $(I S L)$, and real estate $(R E E)$. Significant differences were found in the dependent (earnings attributes and bank risk) and independent (accounting discretion) variables across the bank specialization variable, and hence bank specialization is controlled for in the ensuing analyses. Table 1, Panel C, presents the mean and standard deviation of 
the study variable broken down by bank specialization and crisis period. Panel $\mathrm{C}$ indicates that mean (standard deviation) of $A D$ for BHCs and governmental banks during the non-crisis period ranges from 0.000 for both $(0.001$ and 0.003 , respectively) to 0.034 (0.018) for real estate banks. For the crisis period, mean and standard deviation for $A D$ is lower than their values for the non-crisis period across all specializations (except for mean $A D$ for the Investment specialization). In general, these statistics indicate that accounting discretion is practiced differentially across bank specialization, with the largest $A D$ values residing within the Real Estate and Commercial banks and lowest $A D$ values residing in government banks and BHCs.

Table 1, Panel D, presents the Pearson/Spearman pairwise correlation coefficients for the main study variables. In the non-crisis period, Pearson correlations indicate that accounting discretion is positively associated with earnings smoothness ( 0.239 coefficient, significant at the 1 percent level) and negatively associated with risk-taking (-0.143 coefficient, significant at the 10 percent level). Spearman correlations show negative associations between accounting discretion and earnings persistence (-0.239 coefficient, significant at the 5 percent level) and (marginally) with predictability $(-0.136$, significant at the 10 percent level) and positively associated with $S M O(0.135$, significant at the 10 percent level). The difference between the Spearman and the Pearson correlations stems from the relaxed assumptions underlying the Spearman correlations. The pattern of significant relations is different from that under the non-crisis period, but still supports strong degree of association with earnings persistence. The correlations however do not take into consideration the effects of the control variables, which are incorporated into regression models discussed below.

\section{Empirical Specification}

In this section, the models testing the study hypotheses are specified and the expectations for significant relations delineated.

\subsection{Estimating the Effects of Accounting Discretion and Bank Specialization on Bank-Level Earnings Attributes}

To examine the effects of discretion on earnings persistence, this study augments Equation 2 with additional variables representing accounting discretion $(A D)$, bank specializations (Note 9), two-way interaction between $A D$ and lagged $I N C$, three-way interaction terms among $A D$, lagged $I N C$, and specialization, and a vector of control variables, as shown in Equation $2 *$ below:

$$
\begin{aligned}
I N C_{i t}= & \alpha_{0, \mathrm{i}}+\alpha_{1, \mathrm{i}} I N C_{i t-1}+\alpha_{2, \mathrm{i}} A D_{i t}+\alpha_{3, \mathrm{i}}\left(A D_{i t} * I N C_{i t-1}\right)+\alpha_{4, \mathrm{i}} B H C_{i t}+\alpha_{5, \mathrm{i}} C O M_{i t} \\
& +\alpha_{6, \mathrm{i}} G O V_{i t}+\alpha_{7, \mathrm{i}} I N V_{i t}+\alpha_{8, \mathrm{i}} I S L_{i t}+\alpha_{9, \mathrm{i}} R E E_{i t}+\alpha_{10, \mathrm{i}}\left(A D_{i t} * I N C_{i t-1} * B H C_{i t}\right) \\
& +\alpha_{11, \mathrm{i}}\left(A D_{i t} * I N C_{i t-1} * C O M_{i t}\right)+\alpha_{12, \mathrm{i}}\left(\mathrm{AD}_{\mathrm{it}} * I N C_{i t-1} * G O V_{i t}\right) \\
& +\alpha_{13, \mathrm{i}}\left(A D_{i t} * I N C_{i t-1} * I N V_{i t}\right)+\alpha_{14, \mathrm{i}}\left(A D_{i t} * I N C_{i t-1} * I S L_{i t}\right) \\
& +\alpha_{15, \mathrm{i}}\left(A D_{i t} * I N C_{i t-1} * R E E_{i t}\right)+\alpha_{16, \mathrm{i}} S Z E_{i t}+\alpha_{17, \mathrm{i}} L G R_{i t}+\alpha_{18, \mathrm{i}} L L R_{i t} \\
& +\alpha_{19, \mathrm{i}} A D Q_{i t}+\alpha_{20, \mathrm{i}} C P I_{i t}+\alpha_{21, \mathrm{i}} G P G_{i t}+\mu_{\mathrm{it}}
\end{aligned}
$$

Where $I N C$ is earnings before taxes scaled by lagged total assets; $A D$ is Accounting discretion, measured as the adjusted residuals from Equation 1; BHC, COM, GOV, INV, ISL, REE refers to bank $i$ 's specialization, each bank is assigned to one category: Bank Holding Company (BHC), Commercial (COM), Governmental (GOV), Investment $(I N V)$, Islamic (ISL), or Real Estate (REE); SZE is the natural logarithm of total assets; $L G R$ is the change in loans outstanding over the period deflated by the CPI and scaled by lagged loans outstanding; $L L R$ is the loan loss reserves scaled by total loans; $A D Q$ is the book value of equity reported at the end of the period scaled by end of period total assets; $C P I$ is the consumer price index, year-over-year; $G P G$ is the percent change in GDP per capita.

Equation 2* is estimated using pooled OLS regression and rolling ten-quarter windows over both the non-crisis and the crisis periods for each bank-quarter, yielding bank- and quarter-specific estimates of $\alpha_{1, i}$, which capture the persistence of earnings. Equation $2 *$ also contains the two-way interaction term of $A D$ and $I N C$ to test $\mathrm{H} 1_{P R S}$, as well as the three-way interaction terms of $A D, I N C$ and (one of the six) bank specializations to test $\mathrm{H} 3_{P R S .}$. Prior literature measures persistence as the coefficient on the lagged $I N C\left(\alpha_{1, \mathrm{i}}\right)$ and interprets positive coefficient values as indicative of higher earnings persistence (and quality). However, for purposes of testing $\mathrm{H} 1_{\text {PRS }}$, the variable of interest is the interaction between $A D$ and lagged $I N C$ where this variable shows the incremental effect of $A D$ on earnings persistence. A significant coefficient $\left(\alpha_{3, \mathrm{i}}\right)$ on the interaction of $A D$ and $I N C$ would lend support for $\mathrm{H} 1_{P R S}$. Recall that no prediction is made as to the direction of any of the proposed relations between accounting discretion and earnings attributes or risk.

Similarly, to test whether bank specialization has a moderating effect on the proposed relation between accounting discretion and persistence $\left(\mathrm{H} 3_{P R S}\right)$, the coefficients on the three-way interaction terms between accounting discretion 
$(A D)$, lagged income $(I N C)$, and bank specialization are examined for significance. If one or more of the coefficients on the three-way interactions $\left(\alpha_{10}\right.$ to $\left.\alpha_{15}\right)$ turns out to be significant, the results would suggest that accounting discretion does have an incremental effect on persistence but that this relation is moderated by the type of bank specialization, and hence lend support for $\mathrm{H} 3_{\text {PRS }}$.

Next, the study uses the same approach to examine the effects of discretion on earnings predictability, volatility and smoothness, where the earnings attribute in question ( $P R D$ for predictability, VOL for volatility, and SMO for smoothness) is regressed on accounting discretion $(A D)$, the six bank specializations, two-way interaction terms between $A D$ and specializations, and a vector of control variables, as shown in the general form Equation 4 below:

$$
\begin{aligned}
\text { (Earnings Attribute })_{i t}=\quad & \gamma_{0, i}+\gamma_{1, i} A D_{i t}+\gamma_{2, i} B H C_{i t}+\gamma_{3, i} C O M_{i t}+\gamma_{4, i} G O V_{i t}+\gamma_{5, i} I N V_{i t} \\
& +\gamma_{6, i} I S L_{i t}+\gamma_{7, \mathrm{i}} R E E_{i t}+\gamma_{8, i}\left(A D^{*} B H C\right)_{i t}+\gamma_{9, i}\left(A D^{*} C O M\right)_{i t} \\
& +\gamma_{10, i}(A D * G O)_{i t}+\gamma_{11, i}\left(A D^{*} I N V\right)_{i t}+\gamma_{12, i}\left(A D^{*} I S L\right)_{i t} \\
& +\gamma_{13, i}(A D * R E E)_{i t}+\gamma_{14, i} S Z E_{i t}+\gamma_{15, i} N P L_{i t}+\gamma_{16, i} L L R_{i t} \\
& +\gamma_{17, i} L O A N_{i t}+\gamma_{18, i} I N C_{i t-l}+\gamma_{19, i} A D Q_{i t}+\gamma_{20, i} C P I_{i t} \\
& +\gamma_{21, i} G P G_{i t}+\omega_{i t}
\end{aligned}
$$

Where (Earnings Attribute) ${ }_{i t}$ refers to the respective attribute in question (PRD, VOL, or $\left.S M O\right)$; all variables are as defined in Appendix A. As noted above, this study continues to use Equation $2 *$ (the adapted version of Equation 2a) to derive the measure of earnings predictability, $P R D$, using the bank- and quarter-specific ARl model. The variable $P R D$ is estimated as the standard deviation of the residuals $\left(\mu_{\mathrm{it}}\right)$ from Equation $2 *, P R D=\sqrt{ }\left(\sigma^{2}\left(\mu_{i t}\right)\right)$.

Equation 4 is estimated using pooled OLS regression over both the non-crisis and the crisis periods. To test for the relation between accounting discretion and each of the three earnings attributes (i.e., to test $\mathrm{H}_{P R D}, \mathrm{H} 1_{V O L}, \mathrm{H} 1_{S M O}$ ), the variable of interest is the proxy for accounting discretion, $A D$. A significant coefficient on $A D$ would lend support for $\mathrm{H} 1$ with respect to the attribute tested. Likewise, to test whether bank specialization has a moderating effect on the proposed relation between accounting discretion and each of the three earnings attributes (i.e., to test $\mathrm{H} 3_{P R D}, \mathrm{H} 3_{V O L}, \mathrm{H} 3_{S M O}$ ), the coefficients on the two-way interaction terms between accounting discretion $(A D)$ and bank specialization are examined for significance. If one or more of these coefficients is significant, the results would suggest that accounting discretion does have an incremental effect on the earnings attribute in question but that this relation is moderated by the type of bank specialization, and hence lend support for $\mathrm{H} 3$ with respect to the attribute tested.

\subsection{Estimating the Effects of Accounting Discretion and Bank Specialization on Bank Risk-Taking Behavior}

To examine the effects of discretion on bank risk-taking behavior, bank $z$-scores are regressed on accounting discretion $(A D)$, the six bank specializations, two-way interaction terms between $A D$ and specializations, and a vector of control variables:

$$
\begin{aligned}
\operatorname{RISK}_{i t}= & \lambda_{0, i}+\lambda_{1, i} I N C_{i t-1}+\lambda_{2, i} A D_{i t}+\lambda_{3, i}\left(A D_{i t} * I N C_{i t-1}\right)+\lambda_{4, i} B H C_{i t}+\lambda_{5, i} C O M_{i t} \\
& +\lambda_{6, i} G O V_{i t}+\lambda_{7, i} I N V_{i t}+\lambda_{8, i} I S L_{i t}+\lambda_{9, i} R E E_{i t}+\lambda_{10, i}(A D * B H C)_{i t} \\
& +\lambda_{11, i}(A D * C O M)_{i t}+\lambda_{12, i}(A D * G O V)_{i t}+\lambda_{13, i}(A D * I N V)_{i t} \\
& +\lambda_{14, i}(A D * I S L)_{i t}+\lambda_{15, i}(A D * R E E)_{i t}+\lambda_{16, i} S Z E_{i t}+\lambda_{17, i} L G R_{i t} \\
& +\lambda_{18, i} L L R_{i t}+\lambda_{19, i} A D Q_{i t}+\lambda_{20, i} C P I_{i t}+\lambda_{21, i} G P G_{i t}+s_{i t}
\end{aligned}
$$

Equation 5 is estimated using pooled OLS regression over both the non-crisis and the crisis periods. To test $\mathrm{H} 2$, the variable of interest in Equation 5 is accounting discretion $(A D)$, where a positive relation is expected. Equation 5 also contains the two-way interaction terms of $A D$ and six bank specializations to test $\mathrm{H} 3_{\text {RISK }}$. A significant coefficient on $A D\left(\lambda_{1}\right)$ would lend support for $\mathrm{H} 2$. In addition, to assess whether the effect of accounting discretion on bank risk changes as a function of earnings, Equation 5 also contains the two-way interaction term of $A D$ and $I N C$ to test whether discretion per unit of earnings is positively related to RISK.

Similarly, to test whether bank specialization has a moderating effect on the proposed relation between accounting discretion and bank risk-taking $\left(\mathrm{H}_{\text {RISK }}\right)$, the coefficients on the two-way interaction terms between accounting discretion $(A D)$ and bank specialization are examined for significance. If one or more of the coefficients on the two-way interactions $\left(\lambda_{10}\right.$ to $\left.\alpha_{15}\right)$ turns out to be significant, the results would suggest that the relation between accounting discretion and risk-taking is moderated by the type of bank specialization, and hence lend support for $\mathrm{H} 3_{\text {RISK }}$. 


\section{Empirical Results}

\subsection{Accounting Discretion, Bank Specialization, and Earnings attributes}

Table 3 reports the results of the pooled OLS estimation of Equation 2* (effects of discretion on persistence). The table contains four columns representing four different variations of the basic model (Equation $2 *$ ). Column 1 (Column 2) presents a variation that excludes (includes) accounting discretion tested using non-crisis data. Columns 3 and 4 presents the same $A D$ exclusion/inclusion models tested using crisis data. All four variations are well-specified with adjusted $R^{2}$ of at least 45.70 percent. The models that include accounting discretion (Columns 2 and 4) have slightly higher adjusted $R^{2}$ compared to their counterparts that exclude accounting discretion (Columns 1 and 3) indicating that accounting discretion and its interactions add explanatory power to some extent to the model, especially during the crisis period. After controlling for determinates of earnings, accounting discretion should not have a significant incremental influence on contemporaneous earnings if discretionary behavior was not practiced consistently.

Table 3. The incremental effect of accounting discretion on earnings persistence

\begin{tabular}{|c|c|c|c|c|c|}
\hline \multicolumn{6}{|c|}{ Dependent variable: $I N C$} \\
\hline Variables & $\begin{array}{l}\text { Exp. } \\
\text { sign }\end{array}$ & $\begin{array}{c}\text { Non- } A D \text {, Non-Crisis } \\
\text { (1) }\end{array}$ & $\begin{array}{c}A D \text {, Non-Crisis } \\
\text { (2) }\end{array}$ & $\begin{array}{c}\text { Non- } A D, \text { Crisis } \\
\text { (3) }\end{array}$ & $\begin{array}{c}A D \text {, Crisis } \\
\text { (4) }\end{array}$ \\
\hline Intercept & & $5.5801 * * *(4.2932)$ & $5.5242 * * *(4.2178)$ & $0.2564(0.1298)$ & $-0.1671(-0.0908)$ \\
\hline$I N C_{t-1}$ & & $0.4159 * * *(8.5974)$ & $0.4140 * * *(8.5436)$ & $0.4810 * * *(10.5448)$ & $0.4591 * * *(10.8686)$ \\
\hline$A D$ & & -- & $-0.0919(-0.7958)$ & -- & $-1.0145(-0.6673)$ \\
\hline$A D \times I N C_{t-1}$ & $+/-$ & -- & $0.0383 * * *(3.1621)$ & -- & $0.0481 * *(2.2939)$ \\
\hline$B H C$ & & $1.5065 * * *(3.8582)$ & $1.4710 * * *(3.7376)$ & $-1.4278 * * *(-3.7867)$ & $-1.3546 * * *(-3.9685)$ \\
\hline COM & & $0.3948(0.3930)$ & $0.2621(0.0339)$ & $0.4675(0.4842)$ & $0.8763(0.3039)$ \\
\hline$G O V$ & & $-0.3281 *(-1.8022)$ & $-0.2468(-1.3452)$ & $0.0472(0.2161)$ & $0.0626(0.2959)$ \\
\hline$I N V$ & & $0.2517(1.175)$ & $0.2755(1.284)$ & $-0.0705(-0.2692)$ & $-0.1342(-0.5286)$ \\
\hline ISL & & $0.2135(1.0008)$ & $0.2361(1.0705)$ & $0.1304(0.5029)$ & $0.126(0.5071)$ \\
\hline$R E E$ & & $-0.6561 *(-1.7853)$ & $-0.6291(-1.6026)$ & $-1.7933 * * *(-3.9866)$ & $-1.8904 * * *(-4.5658)$ \\
\hline$A D \times I N C_{-1} \times B H C$ & $+/-$ & -- & $-0.7381 *(-1.6458)$ & -- & $-0.8372 * *(1.8902)$ \\
\hline$A D \times I N C_{-I} \times C O M$ & $+/-$ & -- & $0.1391 *(1.7477)$ & -- & $0.4975^{* * *}(3.2858)$ \\
\hline$A D \times I N C_{-1} \times G O V$ & $+/-$ & -- & $1.092(1.1729)$ & -- & $0.5326 * *(2.1845)$ \\
\hline$A D \times I N C_{-1} \times I N V$ & $+/-$ & -- & $0.8384(0.0732)$ & -- & $1.1688(0.9255)$ \\
\hline$A D \times I N C_{-1} \times I S L$ & $+/-$ & -- & $1.0228(0.4789)$ & -- & $0.3999(0.2787)$ \\
\hline$A D \times I N C_{-1} \times R E E$ & $+/-$ & -- & $1.7733(0.9951)$ & -- & $0.4628(0.9722)$ \\
\hline$S Z E$ & & $0.1041 * *(2.039)$ & $0.1266 * *(2.4249)$ & $0.2279 * * *(2.5949)$ & $0.2162 * * *(2.6323)$ \\
\hline$L G R$ & & $-0.0002(-0.2753)$ & $-0.0001(-0.1082)$ & $-0.0015(-0.9975)$ & $-0.0016(-1.1403)$ \\
\hline$L L R$ & & $-1.1709 * * *(-3.0169)$ & $-1.1404 * * *(-2.9334)$ & $-1.6777 * * *(-5.7442)$ & $-0.7104 * * *(-6.2166)$ \\
\hline$A D Q$ & & $1.8053 * * *(5.8104)$ & $1.9357 * * *(5.929)$ & $1.5604(1.5708)$ & $0.0438(1.3492)$ \\
\hline$C P I$ & & $0.0099(0.3647)$ & $0.0069(0.2545)$ & $-0.0813(-1.4111)$ & $-0.0584(-1.0981)$ \\
\hline$G P G$ & & $-0.0248(-0.4645)$ & $-0.0306(-0.5643)$ & $0.12(1.2968)$ & $0.0864(1.006)$ \\
\hline \multicolumn{6}{|c|}{ Model statistics } \\
\hline \multicolumn{2}{|c|}{ Observations (bank- qtrs) } & 446 & 446 & 188 & 188 \\
\hline \multicolumn{2}{|l|}{$F$-statistic } & $33.8446 * * *$ & $22.7836 * * *$ & $26.4676 * * *$ & $24.6638 * * *$ \\
\hline \multicolumn{2}{|l|}{ Adj. $R^{2}$} & 0.457 & 0.462 & 0.642 & 0.697 \\
\hline
\end{tabular}

$* * *, * *, *$ indicates significance at the $0.01,0.05$ and 0.10 level respectively. Variable definitions are as presented in Appendix A. Table 3 shows coefficient estimates ( $t$-statistics) from the OLS regression of Eq. $2 *$ The four columns 
in the table show estimates for the earnings persistence model variations that include or exclude the $A D$ variable in the non-crisis and crisis periods.

Results from both the non-crisis period indicates that the coefficient of interest in testing $\mathrm{H} 1_{P R S}\left(\alpha_{3, i}\right)$ is significantly positive (non-crisis, 0.0383, significant at the 1 percent level), consistent with accounting discretion having an incremental positive effect on persistence in the non-crisis period. This result lends support for $\mathrm{H}_{P R S}$ for the non-crisis period and is in line with the managerial efficiency view of accounting discretion. However, the same coefficient in the crisis period is insignificant $(0.0481)$, and hence, $\mathrm{H} 1_{P R S}$ is not supported for the crisis period.

The effect of bank specialization on the relation between accounting discretion and earnings persistence is examined next. For the non-crisis period, the results show a marginal incremental negative effect of $A D$ on persistence in the case of BHCs, a marginal incremental positive effect in the case of commercial banks, and no significant incremental effects in the other specializations. In the crisis period, the results indicate a strong incremental negative effect of $A D$ on persistence for BHCs and incremental positive effects of $A D$ on persistence for commercial and governmental banks, lending support for $\mathrm{H} 3{ }_{P R S}$ for these specializations. The results suggest that the effect of $A D$ on earnings persistence and quality should not be examined without incorporating the effect of bank specialization. The results are consistent with an incremental effect for $A D$ on persistence whose direction and significance is a function of bank specialization.

Table 4 reports the results of testing the effects of discretion on predictability (Eq. 4, Dependent variable $=P R D$ ). Model fit statistics indicate that all four models are well specified and have adjusted $R^{2}$ values of at least 25.90 percent. The difference in adjusted $R^{2}$ values between the models that include and those that exclude accounting discretion is 6.5 percent for the non-crisis model but only 0.1 percent for the crisis model. The variable of interest, $A D$, is expected to be (positively or negatively) significant, given the alternative theorizations offered.

Interestingly, the coefficient on $A D$ is (marginally) significantly negative for the non-crisis period (-2.464, significant at the 10 percent level), consistent with accounting discretion increasing, rather than decreasing, earnings predictability. But when taking bank specializations into consideration, the results indicate that specialization dampens the negative effect of discretion on predictability in commercial and Islamic banks and exacerbates it for BHCs. For the crisis period, the coefficient on $A D$ is (marginally) significantly positive (1.330, significant at the 10 percent level), suggesting discretion reducing predictability and lending support for $\mathrm{H} 1_{P R D}$. The coefficients on the three marginally significant interaction terms (commercial, governmental and Islamic banks) carry a negative sign, indicating that specialization dampens the negative effects of accounting discretion on earnings predictability for these specializations during crisis periods. For these specializations, $\mathrm{H} 3_{P R D}$ is supported. 
Table 4 . The incremental effect of accounting discretion on earnings predictability

\begin{tabular}{|c|c|c|c|c|c|}
\hline \multicolumn{6}{|c|}{ Dependent variable: $P R D$} \\
\hline Variable & Exp. sign & $\begin{array}{c}\text { Non- } A D \text {, Non-Crisis } \\
\text { (1) }\end{array}$ & $\begin{array}{c}A D, \text { Non-Crisis } \\
\text { (2) }\end{array}$ & $\begin{array}{c}\text { Non- } A D, \text { Crisis } \\
\text { (3) }\end{array}$ & $\begin{array}{c}A D \text {, Crisis } \\
\text { (4) }\end{array}$ \\
\hline Intercept & & $4.0150 * * *(6.2260)$ & $3.6570 * * *(5.6720)$ & $2.4440 * *(2.2230)$ & $4.2140 * * *(3.5800)$ \\
\hline$A D$ & $+/-$ & -- & $-2.4640 *(-1.6610)$ & -- & $1.3300 *(1.9400)$ \\
\hline$B H C$ & & $2.0510 * * *(8.0660)$ & $2.0790 * * *(8.3900)$ & $1.3170 * * *(2.7810)$ & $1.4740 * * *(3.1120)$ \\
\hline COM & & $-0.4526(-0.4993)$ & $-0.3737(0.3741)$ & $0.0383(0.3391)$ & $0.0383(0.0303)$ \\
\hline$G O V$ & & $-0.2680 * *(-2.2360)$ & $-0.1540(-1.3100)$ & $0.0040(0.0260)$ & $-0.2950(-1.3210)$ \\
\hline$I N V$ & & $0.2250(1.5910)$ & $0.3090 * *(2.1600)$ & $0.2170(1.0860)$ & $0.0520(0.2380)$ \\
\hline$I S L$ & & $-0.0820(-0.5730)$ & $-0.0130(-0.0950)$ & $0.0070(0.0360)$ & $-0.1380(-0.6470)$ \\
\hline$R E E$ & & $0.6580 * * *(2.7270)$ & $0.8150 * * *(3.2140)$ & $0.6820 * *(1.9930)$ & $0.6230 *(1.8090)$ \\
\hline$A D \times B H C$ & $+/-$ & -- & $-1.3760 * * *(-7.1930)$ & -- & $-1.2339(0.2032)$ \\
\hline$A D \times C O M$ & $+/-$ & -- & $1.7340 *(1.7260)$ & -- & $-1.1600 *(-1.9270)$ \\
\hline$A D \times G O V$ & $+/-$ & -- & $-3.3690(-0.0410)$ & -- & $-1.5760 *(-1.9330)$ \\
\hline$A D \times I N V$ & $+/-$ & -- & $3.2470(0.1000)$ & -- & $-1.5810(-0.7710)$ \\
\hline$A D \times I S L$ & $+/-$ & -- & $2.2990 *(1.8070)$ & -- & $-1.0820 *(-1.7550)$ \\
\hline$A D \times R E E$ & $+/-$ & -- & $3.5360(1.0720)$ & -- & $0.9388(1.3441)$ \\
\hline$S Z E$ & & $0.0310(0.4560)$ & $0.0180(0.2690)$ & $0.0410(0.2370)$ & $-0.1320(-0.7560)$ \\
\hline$N P L$ & & $0.4130(0.6220)$ & $0.3170(0.5050)$ & $-0.4190(-0.5110)$ & $-0.3970(-0.4750)$ \\
\hline$L L R$ & & $0.8260 * * *(2.7090)$ & $0.5340 *(1.8050)$ & $1.2770 * * *(3.2510)$ & $1.1440 * * *(2.8860)$ \\
\hline$L O A N$ & & $-0.0120(-0.1760)$ & $-0.0110(-0.1710)$ & $0.0120(0.0680)$ & $0.0690(0.3950)$ \\
\hline$I N C_{t-1}$ & & $0.0670 * *(2.1030)$ & $0.0330(1.0860)$ & $-0.0640 *(-1.8250)$ & $-0.0500(-1.4340)$ \\
\hline$A D Q$ & & $-1.6400 * * *(-7.9720)$ & $-1.9010 * * *(-6.9850)$ & $-1.2440 * * *(-3.7310)$ & $-1.8050 * * *(-3.2080)$ \\
\hline$C P I$ & & $0.0023(0.2435)$ & $-0.0090(-0.5130)$ & $0.0060(0.1260)$ & $0.0140(0.3160)$ \\
\hline$G P G$ & & $0.0076(0.1832)$ & $0.0280(0.8310)$ & $-0.0050(-0.0760)$ & $-0.0270(-0.3800)$ \\
\hline \multicolumn{6}{|c|}{ Model statistics } \\
\hline Observations & (bank- qtrs) & 446 & 446 & 188 & 188 \\
\hline$F$-statistic & & $27.233 * * *$ & $19.998 * * *$ & $6.040 * * *$ & $4.657 * * *$ \\
\hline Adj. $R^{2}$ & & 0.360 & 0.425 & 0.259 & 0.260 \\
\hline
\end{tabular}

$* * *, * *, *$ indicates significance at the $0.01,0.05$ and 0.10 level respectively. Variable definitions are as presented in Appendix A. Table 4 shows coefficient estimates ( $t$-statistics) from OLS regression (Eq. 4) of PRD (earnings predictability, Eq. $2 *$ ).

Table 5 reports the results of testing the effects of discretion on earnings volatility (Eq. 4 , Dependent variable $=$ $V O L)$. Model fit statistics indicate that all four models are well specified and have adjusted $R^{2}$ values of at least 15.60 percent. The difference in adjusted $R^{2}$ values between the models that include and those that exclude accounting discretion is slightly higher for the models that include accounting discretion. The variable of interest, $A D$, is expected to be (positively or negatively) significant, indicating that earnings volatility is associated with accounting discretion. The coefficient on $A D$ is strongly significantly positive for the non-crisis period (1.097, significant at the 1 percent level), consistent with accounting discretion increasing, rather than decreasing, earnings predictability, lending support for $\mathrm{H}_{V O L}$ for the non-crisis period. Bank specialization also appears to dampen the severity of the effect of accounting discretion on earnings volatility in the cases of BHCs, governmental, Islamic and real estate banks. For these specializations, $\mathrm{H} 3_{V O L}$ is supported. For the crisis period, the coefficient on $A D$ is (marginally) significantly negative (-1.036, significant at the 10 percent level) indicating that accounting discretion reduces earnings volatility, hence supporting $\mathrm{H}_{V O L}$ for the crisis period. The coefficients on the three significant interaction 
terms (commercial, governmental and Islamic banks) carry a positive sign, indicating that specialization exacerbates the negative effects of accounting discretion on earnings volatility for these specializations.

Table 5. Effect of accounting discretion on earnings volatility

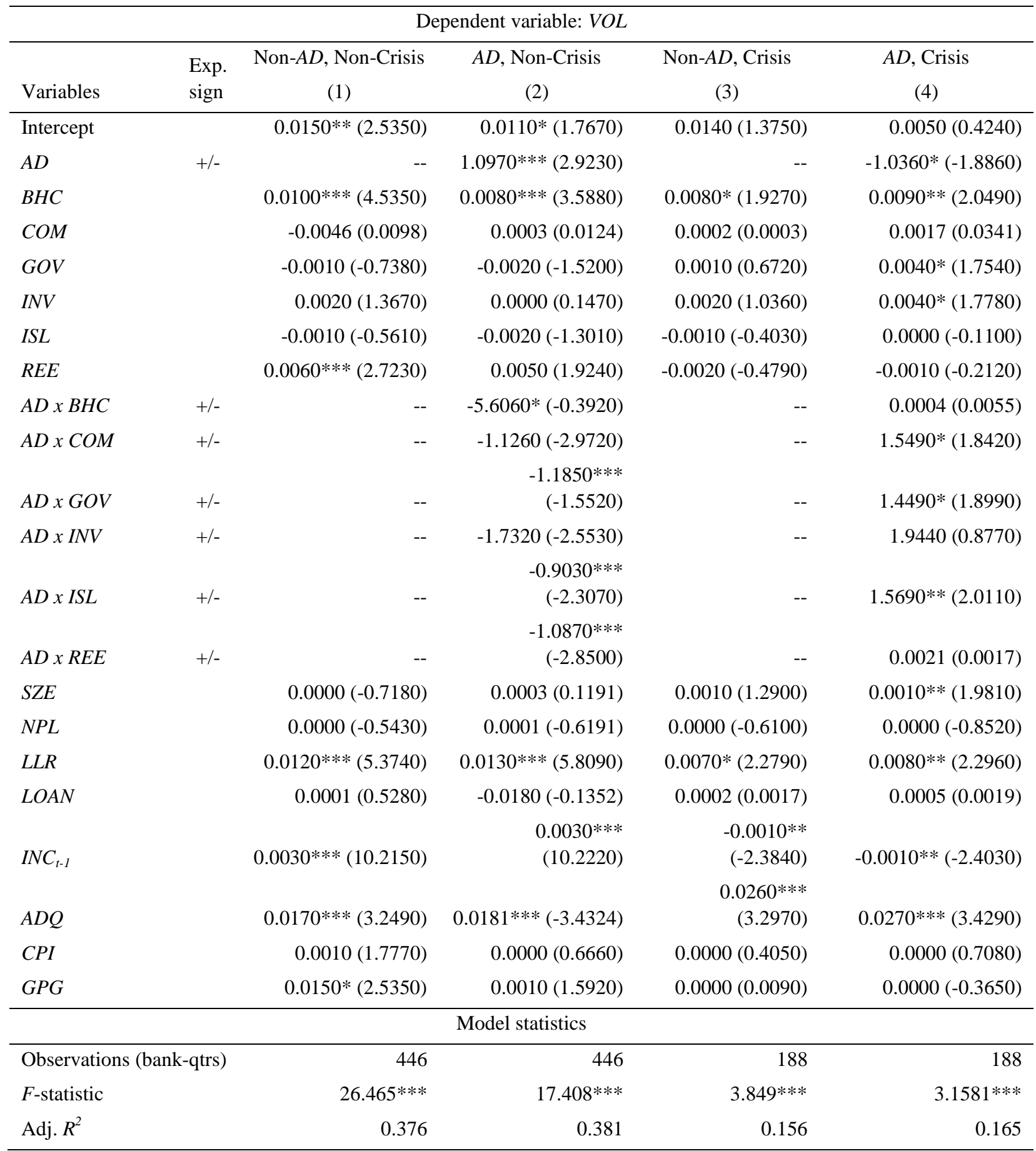

***,**, * indicates significance at the $0.01,0.05$ and 0.10 level respectively. Variable definitions are as presented in Appendix A. Table 5 shows coefficient estimates (t-statistics) from OLS regression (Eq. 4) of VOL (earnings volatility).

Table 6 reports the results of (a) estimating the measure of earnings smoothness in Panel A and (b) testing the effects of discretion on earnings smoothness in Panel B. Recall that the measure of earnings smoothness is estimated as the coefficient of EBLLP in Equation 3. Panel A shows the results of estimating Equation 3 for each specialization/crisis period (12 variants). The model fit statistics vary widely across the variants but all are well-specified with strongly 
significant $f$-statistics. Panel B shows the results of testing the relation between accounting discretion $(A D)$ and earnings smoothness $(S M O)($ Eq. 4 , Dependent variable $=S M O)$. The model fit statistics indicate well-specified models with adjusted $R^{2}$ values of at least 76.40 percent. The difference in adjusted $R^{2}$ values between the models that include and those that exclude accounting discretion is higher for the models that include accounting discretion by a margin of at least 5.6 percent.

The variable of interest, $A D$, is expected to be (positively or negatively) significant, indicating that earnings smoothness is associated with accounting discretion. The coefficient on $A D$ is strongly significantly positive for the non-crisis period (0.6380, significant at the 5 percent level), consistent with accounting discretion increasing, rather than decreasing, earnings predictability, lending support for $\mathrm{H} 1_{S M O}$. Also, the significantly negative coefficients on the interaction terms suggest that bank specialization dampens the relation between accounting discretion and earnings smoothness in the cases of commercial, governmental, Islamic and real estate banks. For these specializations, $\mathrm{H} 3_{S M O}$ is supported. In the crisis period, the coefficient on $A D$ is insignificant, hence rejecting $\mathrm{H} 1_{S M O}$ during the crisis period. The coefficients on the three significant interaction terms are also insignificant, indicating that during the crisis period, accounting discretion is not used to smooth earnings and that specialization does not change this insignificant effect.

Table 6. Accounting discretion and earnings smoothness

Panel A: Estimation of bank-level income smoothness coefficient

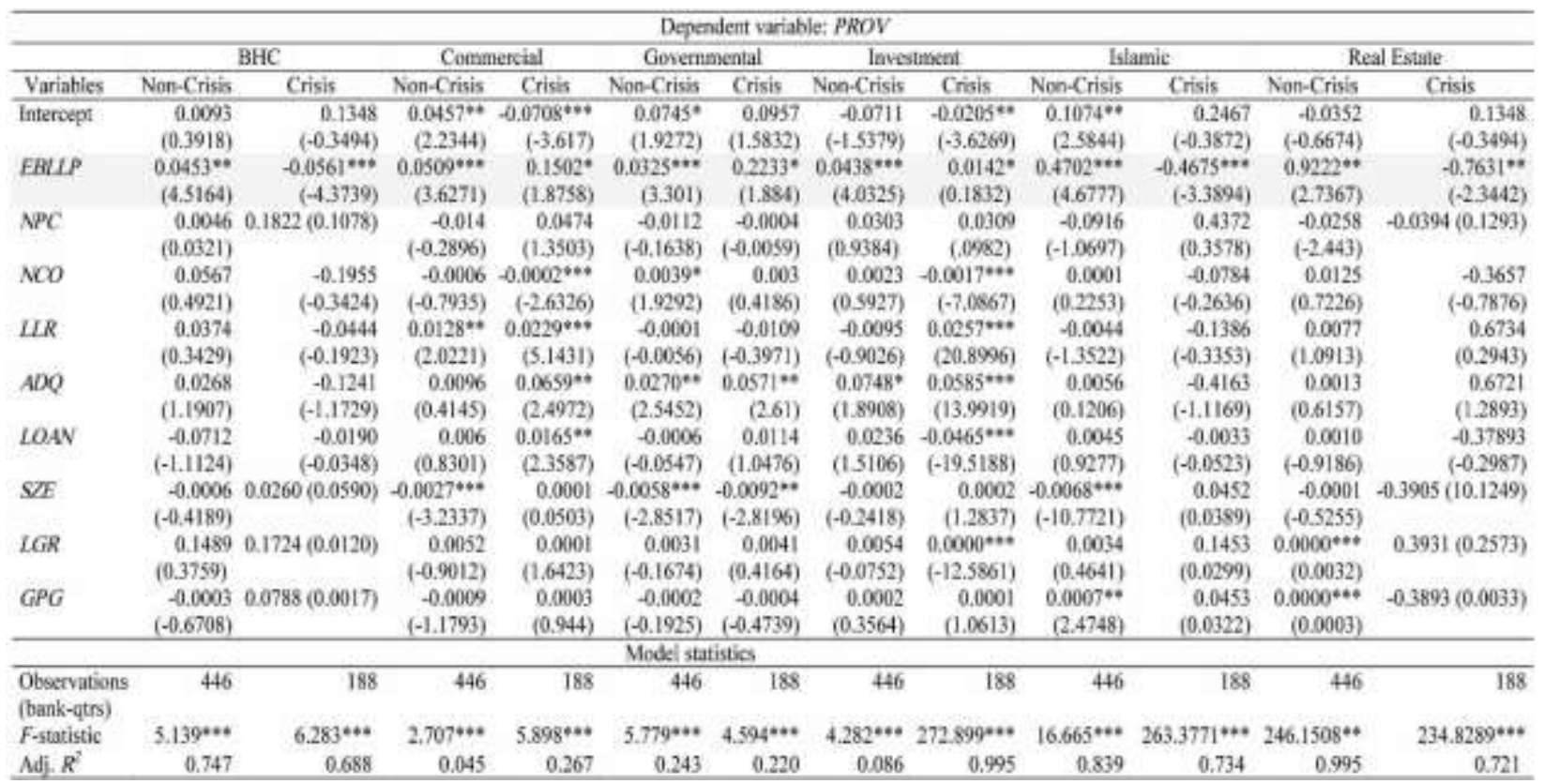

$* * *, * *, *$ indicates significance at the $0.01,0.05$ and 0.10 level respectively. Variable definitions are as presented in Appendix A. Panel A presents the OLS regression results for the model (Eq. 3) used for estimating income smoothness, separately for each of the six bank specializations and for each crisis period. Income smoothness (SMO) is estimated as the coefficient on EBLLP from Equation 3. 
Panel B. The incremental effect of accounting discretion on earnings smoothness

\begin{tabular}{|c|c|c|c|c|c|}
\hline \multicolumn{6}{|c|}{ Dependent variable: $S M O$} \\
\hline Variable & $\begin{array}{l}\text { Exp. } \\
\text { sign }\end{array}$ & $\begin{array}{c}\text { Non- } A D, \\
\text { Non-Crisis } \\
\text { (1) }\end{array}$ & $\begin{array}{c}A D, \text { Non-Crisis } \\
\text { (2) }\end{array}$ & $\begin{array}{c}\text { Non- } A D, \text { Crisis } \\
\text { (3) }\end{array}$ & $\begin{array}{c}A D, \text { Crisis } \\
\text { (4) }\end{array}$ \\
\hline Intercept & & $\begin{array}{r}-0.0837 * * \\
(-2.1032)\end{array}$ & $-0.1363 *(-1.6962)$ & $-0.0087 * *(-2.398)$ & $-0.1076(-1.3379)$ \\
\hline$A D$ & $+/-$ & -- & $0.6380 * *(2.1986)$ & -- & $-2.856(-0.4931)$ \\
\hline $\mathrm{BHC}$ & & $-0.0328 *(-1.8145)$ & $-0.0588 * *(-2.3324)$ & $\begin{array}{r}-0.0263 * * \\
(-2.2833)\end{array}$ & $-0.039(-1.4138)$ \\
\hline GOV & & $-0.4782(-0.3637)$ & $-0.0017(-0.0877)$ & $-0.2683(-0.2793)$ & $0.0148(0.8273)$ \\
\hline$I N V$ & & $0.0484(0.3030)$ & $-0.0465 * * *(-3.4298)$ & $-0.0567(-0.956)$ & $-0.0287 *(-1.7376)$ \\
\hline$I S L$ & & $-0.0647(-0.6840)$ & $0.5501 * * *(41.5433)$ & $0.3983(0.2798)$ & $\begin{array}{r}0.5586^{* * *} \\
(34.7173)\end{array}$ \\
\hline$R E E$ & & $-0.4949(-0.0942)$ & $0.8475 * * *(36.3129)$ & $0.0378(0.1262)$ & $\begin{array}{r}0.8641 * * * \\
(36.5106)\end{array}$ \\
\hline$A D \times B H C$ & $+/-$ & -- & $1.0365(0.1022)$ & -- & $2.0291(0.2742)$ \\
\hline$A D \times C O M$ & $+/-$ & -- & $-1.5154 * *(-2.3705)$ & -- & $1.3047(0.4876)$ \\
\hline$A D \times G O V$ & $+/-$ & -- & $-2.1154 * *(-2.3584)$ & -- & $1.1914(0.4843)$ \\
\hline$A D \times I N V$ & $+/-$ & -- & $-1.2941(-1.3791)$ & -- & $1.1046(0.3804)$ \\
\hline$A D \times I S L$ & $+/-$ & -- & $-1.1131 * * *(-3.0327)$ & -- & $2.4001(1.2011)$ \\
\hline$A D \times R E E$ & $+/-$ & -- & $-1.2478 * *(-2.204)$ & -- & $1.4549(0.3379)$ \\
\hline$S Z E$ & & $0.0038(0.0393)$ & $0.0084(1.3063)$ & $0.0036(0.4803)$ & $0.0083(1.2883)$ \\
\hline$N P L$ & & $0.0067(0.4094)$ & $0.0676(1.2079)$ & $0.0028(0.0073)$ & $0.0736(1.3171)$ \\
\hline$L L R$ & & $0.0282(0.3030)$ & $0.0011(0.0421)$ & $0.0478(0.0083)$ & $-0.0028(-0.1074)$ \\
\hline$L O A N$ & & $0.0038(0.0422)$ & $0.0068(1.0492)$ & $0.0883(0.0489)$ & $0.0053(0.8332)$ \\
\hline$A D Q$ & & $0.0562(0.0373)$ & $0.0572(0.7699)$ & $0.12562(0.37893)$ & $0.0504(0.7465)$ \\
\hline$C P I$ & & $0.0058(0.0330)$ & $0.0009(0.0291)$ & $0.0128(0.0378)$ & $0.0056(0.0034)$ \\
\hline$G P G$ & & $0.0494(0.0339)$ & $0.0058(0.0346)$ & $0.0389(0.0390)$ & $0.0065(0.0887)$ \\
\hline \multicolumn{6}{|c|}{ Model statistics } \\
\hline Observation & -qtrs) & 446 & 446 & 188 & 188 \\
\hline$F$-statistic & & $172.3783 * * *$ & $199.5809 * * *$ & $194.3883 * * *$ & $213.8584 * * *$ \\
\hline Adj. $R^{2}$ & & 0.782 & 0.838 & 0.764 & 0.839 \\
\hline
\end{tabular}

\subsection{Accounting Discretion, Bank Specialization, and Bank Risk-Taking Behavior}

As described earlier, a relation between accounting discretion and bank risk-taking can be concluded (and H2 supported) if the coefficient on $A D$ was found significant. Table 7 reports the results of estimating Equation 5 testing the effects of discretion $(A D)$ on risk-taking $(R I S K)$. As with the empirical tests conducted thus far, four model variations were run shown representing $A D$, non- $A D$, crisis, and non-crisis variants. Model fit statistics indicate that all four models are well specified and have adjusted $R^{2}$ values of at least 12.80 percent. The difference in adjusted $R^{2}$ values between the models that include and those that exclude accounting discretion is at least 1 percent (6.2 percent in the case of non-crisis period) higher for the models that include accounting discretion. 
Table 7. Effect of accounting discretion on bank risk-taking behavior

\begin{tabular}{|c|c|c|c|c|c|}
\hline \multicolumn{6}{|c|}{ Dependent variable: $R I S K$} \\
\hline \multirow[b]{2}{*}{ Variables } & Exp. & Non- $A D$, Non-Crisis & $A D$, Non-Crisis & Non- $A D$, Crisis & $A D$, Crisis \\
\hline & sign & (1) & (2) & (3) & (4) \\
\hline \multicolumn{2}{|l|}{ Intercept } & $5.038 * * *(9.7450)$ & $5.4836 * * *(8.1539)$ & $7.552 * * *(7.2462)$ & $8.6590 * * *(7.7760)$ \\
\hline \multicolumn{2}{|l|}{$I N C_{t-1}$} & $0.0011(0.0510)$ & $0.0098(0.4001)$ & $0.0742 * *(2.2341)$ & $0.0750 * *(2.2660)$ \\
\hline$A D$ & $+/-$ & -- & $-1.4287 * * *(-3.3431)$ & -- & $3.6940 * *(2.3000)$ \\
\hline \multicolumn{2}{|l|}{$A D \times I N C_{t-1}$} & -- & $-1.0276 * * *(-2.5934)$ & -- & $-1.7700(-0.0710)$ \\
\hline \multicolumn{2}{|l|}{$B H C$} & $-0.8111 * * *(4.0783)$ & $-0.6314 * * *(-3.1076)$ & $-1.122 * * *(-2.5211)$ & $-1.2010 * * *(-2.7010)$ \\
\hline \multicolumn{2}{|l|}{ COM } & $0.0001(0.0002)$ & $-0.0339(-0.0932)$ & $-0.0001(-.0003)$ & $0.0070(0.0044)$ \\
\hline \multicolumn{2}{|l|}{ GOV } & $-0.1002 *(-1.064)$ & $-0.0455(-0.4785)$ & $-0.2264(-1.4322)$ & $-0.5220 * *(-2.5080)$ \\
\hline \multicolumn{2}{|l|}{$I N V$} & $-0.216 * *(-1.9491)$ & $-0.0613(-0.5305)$ & $-0.2051(-1.0842)$ & $-0.3890 * *(-1.9040)$ \\
\hline \multicolumn{2}{|l|}{$I S L$} & $-0.0371(-0.3372)$ & $0.0831(0.7216)$ & $-0.1891(-1.0101)$ & $-0.2760(-1.3870)$ \\
\hline \multicolumn{2}{|l|}{$R E E$} & $-0.6961 * * *(-3.6711)$ & $-0.5747 * * *(-2.8005)$ & $-0.405(-1.2501)$ & $-0.5050(-1.5520)$ \\
\hline \multicolumn{2}{|l|}{$A D \times B H C$} & -- & $1.2502 * * *(4.4637)$ & -- & $0.0010(0.0023)$ \\
\hline$A D \times C O M$ & $+/-$ & -- & $1.2209 * * *(3.3095)$ & -- & $-1.2460 * *(-2.2510)$ \\
\hline$A D \times G O V$ & $+/-$ & -- & $0.8103(1.1845)$ & -- & $-1.1710 * *(-2.2910)$ \\
\hline$A D \times I N V$ & $+/-$ & -- & $1.9474 * * *(2.9599)$ & -- & $-2.5930(-1.2370)$ \\
\hline$A D \times I S L$ & $+/-$ & -- & $1.2124 * *(2.4401)$ & -- & $-1.1850 * *(-2.3520)$ \\
\hline$A D \times R E E$ & $+/-$ & -- & $1.2204 * * *(3.4153)$ & -- & $0.0082 * * *(0.0012)$ \\
\hline \multicolumn{2}{|l|}{$S Z E$} & $0.0452(1.519)$ & $0.0294(1.0875)$ & $-0.1671 * * *(-2.6351)$ & $-0.2210 *(-3.2980)$ \\
\hline \multicolumn{2}{|l|}{$L G R$} & $0.0003(0.0007)$ & $0.0002(-0.0169)$ & $0.0003(0.0321)$ & $0.0000(0.2560)$ \\
\hline \multicolumn{2}{|l|}{$L L R$} & $-0.8822 * * *(-4.1031)$ & $-0.9231 * * *(-4.5946)$ & $-1.1451 * * *(-3.4001)$ & $-1.1470 * * *(-3.3190)$ \\
\hline \multicolumn{2}{|l|}{$A D Q$} & $2.3153 * * *(-5.0772)$ & $1.4771 * * *(4.2205)$ & $1.2243(-1.4801)$ & $1.1280(1.3600)$ \\
\hline \multicolumn{2}{|l|}{$C P I$} & $0.0041(-0.3111)$ & $0.0014(0.1057)$ & $0.0151(0.3683)$ & $0.0000(-0.0070)$ \\
\hline \multicolumn{2}{|l|}{$G P G$} & $-.0351(-1.2843)$ & $-0.0372(-1.3477)$ & $-0.1071(-1.6062)$ & $-0.0760(-1.1190)$ \\
\hline \multicolumn{6}{|c|}{ Model statistics } \\
\hline \multicolumn{2}{|c|}{ Observations (bank-qtrs) } & 446 & 446 & 188 & 188 \\
\hline \multicolumn{2}{|c|}{$F$-statistic } & $7.221 * * *$ & $6.455 * * *$ & $5.156 * * *$ & $3.953 * * *$ \\
\hline \multicolumn{2}{|c|}{ Adj. $R^{2}$} & 0.128 & 0.184 & 0.212 & 0.223 \\
\hline
\end{tabular}

$* * *, * *, *$ indicates significance at the $0.01,0.05$ and 0.10 level respectively. Variable definitions are as presented in Appendix A. Table 7 shows coefficient estimates (t-statistics) from OLS regression (Eq. 5) of RISK (proxy for bank risk-taking behavior with larger values indicating more risk.

The coefficient on $A D$ is strongly significantly negative for the non-crisis period $(-1.4287$, significant at the 1 percent level) but significantly positive for the crisis period (3.6940, significant at the 5 percent level). The negative (positive) coefficient is consistent with accounting discretion impairing (improving) market disciplining over bank risk-taking during non-crisis (crisis) periods, potentially due to the increased (decreased) earnings volatility during that period. The results lend support for H2. The results also suggest that the relation between discretion and risk-taking is dampened by the effect of including the specialization information. In the non-crisis period, five out of the six interaction terms are significant (BHCs, commercial, governmental, investment, Islamic and real estate banks), lending support for $\mathrm{H}_{1}$ RISK with respect to these banks. For these bank types, bank specialization increases the risk effects of accounting discretion. For the crisis period, the results suggest that the relation between accounting discretion and bank risk-taking is significantly negative for commercial, governmental, and Islamic banks, consistent with the risk effects of accounting discretion being exacerbated for these banks. Results also show significantly positive for real estate banks, consistent with risk effects of accounting discretion being dampened (decreased) for 
this type of banks. It is concluded on the basis of the significant results that $\mathrm{H} 3_{\text {RISK }}$ is supported for the significant relations.

In addition to the above analysis, the interaction of accounting discretion and lagged income $\left(A D \times I N C_{t-I}\right)$ is examined. This interaction term represents the accounting discretion per unit of income. It is interesting to ask whether the relation between $A D$ and risk-taking is a function of bank profitability. In other words, are managers more (or less) aggressive in their discretionary practices at different profitability levels and, if so, does this dependency impact the effect of accounting discretion on bank risk? To seek answers to these questions, the coefficient on the interaction term $A D x I N C_{t-1}$ is examined. In the non-crisis period, the coefficient is significantly negative (-1.0276, significant at the 1 percent level) but is insignificant in the crisis period. This is consistent with accounting discretion being more aggressive, and hence reduces stability of bank earnings' stream, at higher income levels during non-crisis periods, possibly as a result of income smoothing. During the crisis period, the negative impact of the crisis reaches all banks and losses are expected, and bank managers do not see a need to increase the severity of their discretionary practices in response to unfavorable business conditions.

\section{Conclusion}

\subsection{Discussion}

The Egyptian banking sector underwent structural reforms instituted in the early 2000s to increase the competitiveness of Egyptian banks. These reforms consolidated the banking sector into larger, more adequately capitalized financial institutions, with widely divergent ownership and governance structures (e.g., foreign and/or institutional ownership), that follow strict minimum capital requirements rules. These new realities, coupled with increased competition and the emergence of economic and political crises, have resulted in widely divergent discretionary accounting practices. As can be seen in Table 1, Panel B, the measure representing accounting discretion ranges from -2 percent to 6 percent of total bank assets and differs according to bank specialization (type). While governmental banks have to follow mandated accounting rules, commercial banks follow more diverse accounting practices because they saw a large increase in foreign presence as a result of the measures taken by the Egyptian Banking Act to modernize the banking sector. Banks whose ownership is dominated by foreign (and institutional) owners espouse different managerial philosophies and accounting practices than purely local, state-owned banks. It is also interesting to note that the positive serial autocorrelation found between accounting discretion and prior year's discretion (see Table 1, Panel B) indicates that managers use their discretion strategically, rather than with a short-term, single-year focus.

The study questions whether on the aggregate the Egyptian banking reforms facilitate market disciplining of banks, given the accounting discretion it caused. Market participants are better able to discipline bank managers when the quality of accounting information improves (declines). To determine whether the reforms facilitate market discipline of banks, the study examines the differential impact of accounting discretion on the quality of accounting information reported by banks and the risk-taking behaviors of their managers. In doing so, the question is raised regarding whether the incentives underlying discretionary accounting practices in Egyptian banks mostly opportunistic or efficient? Prior literature is mixed on whether higher accounting discretion is beneficial or detrimental to the interests of capital market participants. However, positive accounting theory studies contend that discretion may be opportunistic or efficient. If discretion is opportunistic (impairs earnings quality and increases bank risk), then an unintended consequence of the reforms was deterring market disciplining of banks, because market (and regulatory) disciplining requires transparent accounting information. If, on the other hand, discretion is efficient (improved fundamental earnings attributes and reduces risk), then the reforms successfully managed to facilitate market discipline.

Based on a sample of 46 banks providing 634 bank-quarters over the period 2000-2015, the results indicate that, during normal years of operations, bank managers engage in accounting discretionary activities (related to loan loss provisioning) that improve the persistence, predictability and smoothness of earnings but that this improvement in earnings attributes come at the expense of higher earnings volatility. On the other hand, during years of economic or political crises, accounting discretion is associated with higher persistence, lower predictability and volatility and has no effect on smoothing. Therefore, it may be argued that accounting discretionary behavior of bank managers has different goals during the non-crisis and crisis periods. During the non-crisis period, managers use their discretion to create a smooth stream of earnings in order to increase persistence and predictive value of the reported figures, with little concern for controlling earnings volatility. However, during the crisis period, bank managers shift their attention to the reduction of the volatility in earnings caused by the crisis. Their efforts lead to higher earnings persistence and lower volatility, but predictability suffers because smoothing activities taken in previous years were 
interrupted by the crisis. This interpretation of managers' discretionary behavior is consistent with managerial efficiency and not managerial opportunism explanation of earnings management.

The study also finds that the increase in accounting discretion is associated with higher bank risk-taking behavior during the non-crisis period, which can be interpreted as a negative effect for discretion on the market disciplining of bank risk-taking behavior. In line with the managerial efficiency perspective, managers use their discretion to smooth earnings out and, in doing so, their practices increase earnings volatility and information risk and decrease transparency. The higher earnings volatility increase bank risk-taking. On the other hand, during the crisis periods, the use of increased accounting discretion is associated with lower risk, because discretion involved in stabilizing earnings during crisis periods reduce earnings volatility, information risk and consequently bank risk-taking. Specialization in operations is also found to have an exacerbating or mitigating effect on the relation between accounting discretion, earnings attributes and bank risk-taking.

\subsection{Contributions, Policy Implications, Limitations and Future Research}

The paper makes a number of timely contributions to the extant literature and has policy implications for future regulatory developments in the banking industry. First, it complements and extends the literature on the role of market discipline in the regulation of banks. Second, the study uses a unique context to examine the proposed relations. The Egyptian banking sector has shown resilience in the face of economic and political downturns, but the risky environment within which it operates makes it an ideal setting for studying the impact on risk compared to other settings where risk is only systematic. Third, the impact of discretionary LLP on bank risk-taking through its effects on earnings informational attributes has not been studied previously. Other studies relate discretion and accruals but do not consider these attributes. Fourth, the study argues that the objectives behind discretionary activities are context-based. That is, during crises periods, banks may use accounting discretion to contain volatility, whereas during non-crisis period discretion is exercised for smoothing out earnings.

The study has policy implications that may be of interest to regulators and the banking community. Market discipline can be used for prudential oversight over banks only if managerial intent behind discretionary LLP behavior is efficient and not opportunistic. Efficient (opportunistic) discretion results in higher (lower) quality earnings. The CBE could enhance the informativeness of bank earnings by examining whether the informational attributes of these earnings are improving or deteriorating over time. Higher quality earnings translate into better decisions and lower risk for investors, depositors and borrowers. The CBE could also examine the relation between discretionary LLP, capital adequacy, liquidity and risk to determine which banks are more likely to engage in unacceptable discretionary practices. Bank financial information may form the basis for contractual agreements between the bank and CBE, bank managers, and borrowers. Based on the results of this study, managers use discretion in preparing this financial information, which in turn may affect bank contractual obligations positively or negatively. Effective monitoring of bank discretionary activities would ensure that bank managers discharge their responsibilities under these contractual obligations effectively.

The study results should be interpreted in the context of certain limitations. The empirical results are only valid to the extent that data used to test the hypothesis is free from measurement error. The measures of the study variables are assumed to be reliable, unbiased estimators of the underlying constructs (Dechow \& Dichev, 2002). To the extent that this is a valid assumption, study results may be credible. Furthermore, if the crisis periods assumed in this study are not well-aligned with the factual crisis periods, the results may not be valid. Future research may investigate multiple measures of accounting discretion, since the one used in this study captures loan loss provisioning only. Also, it should be interesting to understand the conditions and/or the contexts under which banks practice efficient versus opportunistic discretion. Attempts to address this question are plentiful in industrial, but not in financial institution, settings (Christie and Zimmerman, 1994).

\section{References}

Affleck-Graves, J., Callahan, C.M., \& Chipalkatti, N. (2002). Earnings Predictability, Information Asymmetry, and market liquidity. Journal of Accounting Research, 40(3), 561-83. http://dx.doi.org/10.1111/1475-679X.00062

Antle, R., \& Smith, A. (1986). An empirical investigation of the relative evaluation of corporate executives. Journal of Accounting Research, 24(1), 1-39. HTTP://DX.DOI.ORG/10.2307/2490802

Arya, A., Glover, J., \& Sunder, S. (2003). Are unmanaged earnings always better for shareholders?. Accounting Horizons, 17(Supplement), 111-16. http://dx.doi.org/10.2308/acch.2003.17.s-1.111

Baele, L., De Jonghe, O., \& Vander Vennet, R. (2007). Does the stock market value bank diversification?. Journal of Banking \& Finance, 31(7), 1999-2023. http://dx.doi.org/10.1016/j.jbankfin.2006.08.003 
Barth, J., Caprio, G., \& Levine, R. (2004). Bank supervision and regulation: What works best? Journal of Financial Intermediation, 13(2), 205-48. http://dx.doi.org/10.1016/j.jfi.2003.06.002

Basel Committee on Banking Supervision. (1991). Proposals for the inclusion of general provisions and general loan-loss reserves in capital. February, Bank for International Settlements.

Basel Committee on Banking Supervision. (2001). The New Basel Capital Accord. Basel Committee on Banking Supervision, Second Consultative Paper. January. Basel, Switzerland.

Beatty, A., Ke, B., \& Petroni, K.R. (2002). Earnings management to avoid earnings declines across publicly and privately held banks. The Accounting Review, 77(3), 547-70. http://dx.doi.org/10.2308/accr.2002.77.3.547

Berger, A., \& DeYoung, R. (1997). Problem loans and cost efficiency in commercial banks. Journal of Banking \& Finance, 21(6), 849-70. http://dx.doi.org/10.1016/S0378-4266(97)00003-4

Bharath, S.T., Sunder, J., \& Sunder, S.V. (2008). Accounting quality and debt contracting. The Accounting Review, 83(1), 1-28. http://dx.doi.org/10.2308/accr.2008.83.1.1

Bikker, J.A., \& Metzemakers, P.A. (2005). Bank provisioning behaviour and procyclicality. Journal of International Financial Markets, Institutions and Money, 15(2), 141-57. http://dx.doi.org/10.1016/j.intfin.2004.03.004

Bowen, R.M., Rajgopal, S., \& Venkatachalam, M. (2008). Accounting discretion, corporate governance, and firm performance. Contemporary Accounting Research, 25(2), 351-405. HTTP://DX.DOI.ORG/10.1506/car.25.2.3

Bramble, H.A. (1990). The use of accounting ratios as measures of risk in the determination of bid-ask Spread. Ph.D. Dissertation, University of Houston.

Brennan, M., Chordia, T., \& Subrahmanyam, A. (1998). Alternative factor specifications, security characteristics and the cross-section of expected stock returns. Journal of Financial Economics, 49(3), 345-73. http://dx.doi.org/10.1016/S0304-405X(98)00028-2

Bushman, R.M., \& Williams, C.D. (2012). Accounting discretion, loan loss provisioning, and discipline of banks' risk-taking. Journal of Accounting and Economics, 54(1), 1-18. http://dx.doi.org/10.1016/j.jacceco.2012.04.002

Christie, A., \& Zimmerman, J. (1994). Efficient and opportunistic choices of accounting procedures: Corporate control contests. The Accounting Review, 69(4), 539-66

Cohen, L.J., Cornett, M.M., Marcus, A.J., \& Tehranian, H. (2014). Bank earnings management and tail risk during the financial crisis. Journal of Money, Credit and Banking, 46(1), 171-97. HTTP://DX.DOI.ORG/10.1111/jmcb.12101

Crabtree, A.D., \& Maher, J.J. (2005). Earnings predictability, bond ratings, and bond yields. Review of Quantitative Finance and Accounting, 25(3), 233-53. HTTP://DX.DOI.ORG/10.1007/s11156-005-4766-2

Dechow, P.M., \& Dichev, I.D. (2002). The quality of accruals and earnings: The role of accrual estimation errors. The Accounting Review, 77 (Supplement), 35-59. http://dx.doi.org/10.2308/accr.2002.77.s-1.35.

DeYoung, R., \& Roland, K.P. (2001). Product mix and earnings volatility at commercial banks: Evidence from a degree of leverage model. Journal of Financial Intermediation, 10(1), 54-84. http://dx.doi.org/10.1006/jfin.2000.0305

Diamond, D.W. (1996). Financial intermediation as delegated monitoring: A simple example. Federal Reserve Bank of Richmond Economic Quarterly, 82(3), 51-66.

Düllmann, K., \& Masschelein, N. (2007). A tractable model to measure sector concentration risk in credit portfolios. Journal of Financial Services Research, 32(1-2), 55-79. http://dx.doi.org/10.1007/s10693-007-0014-3

Easley, D., \& O'Hara, M. (2004). Information and the cost of capital. Journal of Finance, 59(4): 1553-83. http://dx.doi.org/10.1111/j.1540-6261.2004.00672.x

Fan, J., \& Wong, T. (2002). Corporate ownership structure and the informativeness of accounting earnings in east Asia. Journal of Accounting \& Economics, 33(3), 401-26. http://dx.doi.org/10.1016/S0165-4101(02)00047-2

Flannery, M., \& Thakor, A. (2006). Accounting, transparency and bank stability. Journal of Financial Intermediation, 15(3), 281-84. http://dx.doi.org/10.1016/j.jfi.2006.05.001

Fonseca, A.R., \& González, F. (2008). Cross-country determinants of bank income smoothing by managing loan-loss provisions. Journal of Banking \& Finance, 32(2), 217-28. http://dx.doi.org/10.1016/j.jbankfin.2007.02.012

Foos, D., Norden, L., \& Weber, M. (2010). Loan growth and riskiness of banks. Journal of Banking \& 
Finance, 34(12), 2929-40. http://dx.doi.org/10.1016/j.jbankfin.2010.06.007

Francis, J., LaFond, R., Olsson, P., \& Schipper, K. (2003). Earnings quality and the pricing effects of earnings patterns. Working paper, Duke University, University of Wisconsin and the FASB.

Francis, J., LaFond, R., Olsson, P., \& Schipper, K. (2004). Costs of equity and earnings attributes. The Accounting Review, 79(4), 967-1010. http://dx.doi.org/10.2308/accr.2004.79.4.967

Francis, B., Hasan, I., Koetter, M., \& Wu, Q. (2012). Corporate boards and bank loan contracting. Journal of Financial Research, 35(4), 521-52. http://dx.doi.org/10.1111/j.1475-6803.2012.01327.x

Graham, J.R., Harvey, C.R., \& Rajgopal, S. (2005). The economic implications of corporate financial reporting. Journal of Accounting \& Economics, 40(1), 3-73. http://dx.doi.org/10.1016/j.jacceco.2005.01.002

Graham, J.R., Li, S., \& Qiu, J. (2008). Corporate misreporting and bank loan contracting. Journal of Financial Economics, 89(1), 44-61. http://dx.doi.org/10.1016/j.jfineco.2007.08.005

Greenspan, A. (2003, May 8). Remarks. Delivered via satellite at the 39th Conference on Bank Structure and Competition, Federal Reserve Bank of Chicago, IL.

Hamadi, M., Heinen, A., Linder, S., \& Porumb, V. A. (2016). Does Basel II affect the market valuation of discretionary loan loss provisions?. Journal of Banking \& Finance, 70(September), 177-92. http://dx.doi.org/10.1016/j.jbankfin.2016.06.002

Hayden, E., Porath, D., \& von Westernhagen, N. (2007). Does diversification improve the performance of German banks? Evidence from individual bank loan portfolios. Journal of Financial Services Research, 32(3), 123-40. HTTP://DX.DOI.ORG/10.1007/s10693-009-0066-7

Huizinga, H., \& Laeven, L. (2009). Accounting discretion of banks during a financial crisis. Working Paper, IMF.

Jin, J., Kanagaretnam, K., \& Lobo, G.J. (2016). Discretion in bank loan loss allowance, risk taking and earnings management. Accounting \& Finance, forthcoming. HTTP://DX.DOI.ORG/10.1111/acfi.12210

Laeven, L., \& Majnoni, G. (2003). Loan loss provisioning and economic slowdowns: Too much, too late?. Journal of Financial Intermediation, 12(2), 178-97. http://dx.doi.org/10.1016/S1042-9573(03)00016-0

Liu, C., \& Ryan, S. (2006). Income smoothing over the business cycle: Changes in banks' coordinated management of provisions for loan losses and loan charge-offs form the pre-1990 bust to the 1990s boom. The Accounting Review, 81(2), 421-41. http://dx.doi.org/10.2308/accr.2006.81.2.421

Lobo, G.J., \& Yang, D.H. (2001). Bank managers' heterogeneous decisions on discretionary loan-loss provisions. Review of Quantitative Finance and Accounting, 16(3), 223-50. HTTP://DX.DOI.ORG/10.1023/A:1011284303517

Luttman, S.M. \& Silhan, P.A. (2011). An empirical analysis of the Value Line earnings predictability index." Journal of Applied Business Research, 9(4), 104-9. http://dx.doi.org/10.19030/jabr.v9i4.6000

Ma, M.L., \& Song, V. (2016). Discretionary loan loss provisions and systemic risk in the banking industry. Accounting Perspectives, 15(2), 89-130. HTTP://DX.DOI.ORG/10.1111/1911-3838.12091

Nier, E., \& Baumann, U. (2006). Market discipline, disclosure and moral hazard in banking. Journal of Financial Intermediation, 15(3), 332-61. http://dx.doi.org/10.1016/j.jfi.2006.03.001

Richardson, S. (2003). Earnings surprises and short selling. Accounting Horizons, 17 (Supplement): $49-61$. http://dx.doi.org/10.2308/acch.2003.17.s-1.49

Rochet, J.C. (2005). Prudential Policy. Monetary and Economic Studies, 23(Special Edition), 93-119.

Schipper, K., \& Vincent, L. (2003). Earnings quality. Accounting Horizons, 17(Supplement), 97-110. http://dx.doi.org/10.2308/acch.2003.17.s-1.97

Stever, R. (2007). Bank size, credit and the sources of bank market risk. BIS Working Paper no. 238 , Basel. http://dx.doi.org/10.2139/ssrn.890658

Stiroh, K.J. (2004). Diversification in banking: Is non-interest income the answer? Journal of Money, Credit, \& Banking, 36(5), 853-82. HTTP://DX.DOI.ORG/10.1353/mcb.2004.0076

Stiroh, K.J. (2006a). New evidence on the determinants of bank risk. Journal of Financial Services Research, 30(3), 237-63. HTTP://DX.DOI.ORG/10.1007/s10693-006-0418-5 
Stiroh, K.J. (2006b). A portfolio view of banking with interest and noninterest activities. Journal of Money, Credit, \& Banking, 38(5), 1351-61. HTTP://DX.DOI.ORG/10.1353/mcb.2006.0075

Subramanyam, K.R. (1996). The pricing of discretionary accruals. Journal of Accounting \& Economics, 22(1-3), 249-81. http://dx.doi.org/10.1016/S0165-4101(96)00434-X

Vyas, D. (2009). Financial reporting transparency of US financial institutions during the current economic crisis. Working Paper, University of Toronto.

Wall, L., \& Koch, T. (2000). Bank loan-loss accounting: a review of theoretical and empirical evidence. Economic Review, 85(2), 1-19.

\section{Notes}

Note 1. Prior research argues that managerial opportunism and efficiency are not mutually exclusive (Christie \& Zimmerman, 1994). However, since hypotheses are stated in a non-directional form, the research design followed in this study spares the need to test for both theories. The empirical results drive the conclusion about whether managerial discretionary behaviors are opportunistic or efficient.

Note 2. Managerial opportunism involves risk shifting where bank managers benefit themselves at the expense of deposit holders by increasing the risk of asset portfolios without adequately increasing bank capital.

Note 3. The second round of Basel Accords prescribes three "pillars" in banking regulation: minimum capital standards, supervisory review, and market discipline. Pillar three is the primary focus of this study.

Note 4. The current version of the EAS was issued by a ministerial Decree (No. 243/2006 of the Minister of Investment) in 2006 and formally adopted 35 international accounting standards issued by the International Accounting Standards Committee. In case where no guidance can be found in EAS, Egyptian banks are required to follow the International Financial Reporting Standards issued by the now International Accounting Standards Board.

Note 5. Increased disclosures could merely translate into more information but not necessarily higher transparency. Transparency is a concept that involves rational placement of information into meaningful contexts (Greenspan, 2003). Banks, in particular, have high-risk exposures and complex operations and the mere provision of additional information (for regulatory purposes or otherwise) may not make a bank more transparent.

Note 6. Some empirical evidence in the literature suggests otherwise (Stiroh, 2006b).

Note 7. The original Beatty et al. (2002) model decomposes total loans into loan types (commercial and industrial, real estate, agricultural, consumer, loans to foreign governments and loans to banks). However, due to the lack of availability of this detailed data for Egyptian banks on Bankscope, this study uses instead the total loans outstanding (which sums up the six types of loans into one total figure).

Note 8 . The current IFRS requirements for provisioning require that a provision for loan losses be recorded only after loss impairment events have already occurred prior to the financial reporting date that are likely to result in non-payment of loans in the future (Bushman \& Williams, 2012).

Note 9. The six bank specializations are included in the test model as six dummy variables rather than one multi-level categorical variable for two reasons. First, there is no theoretical reasoning for ordering the specializations according to specific criteria. Second, bank specialization itself is only examined in this study to the extent of its interaction with accounting discretion and this interaction must be examined separately per specialization if any meaningful interpretation is to be deduced about each specialization. 


\section{Appendix (A): Variable definition}

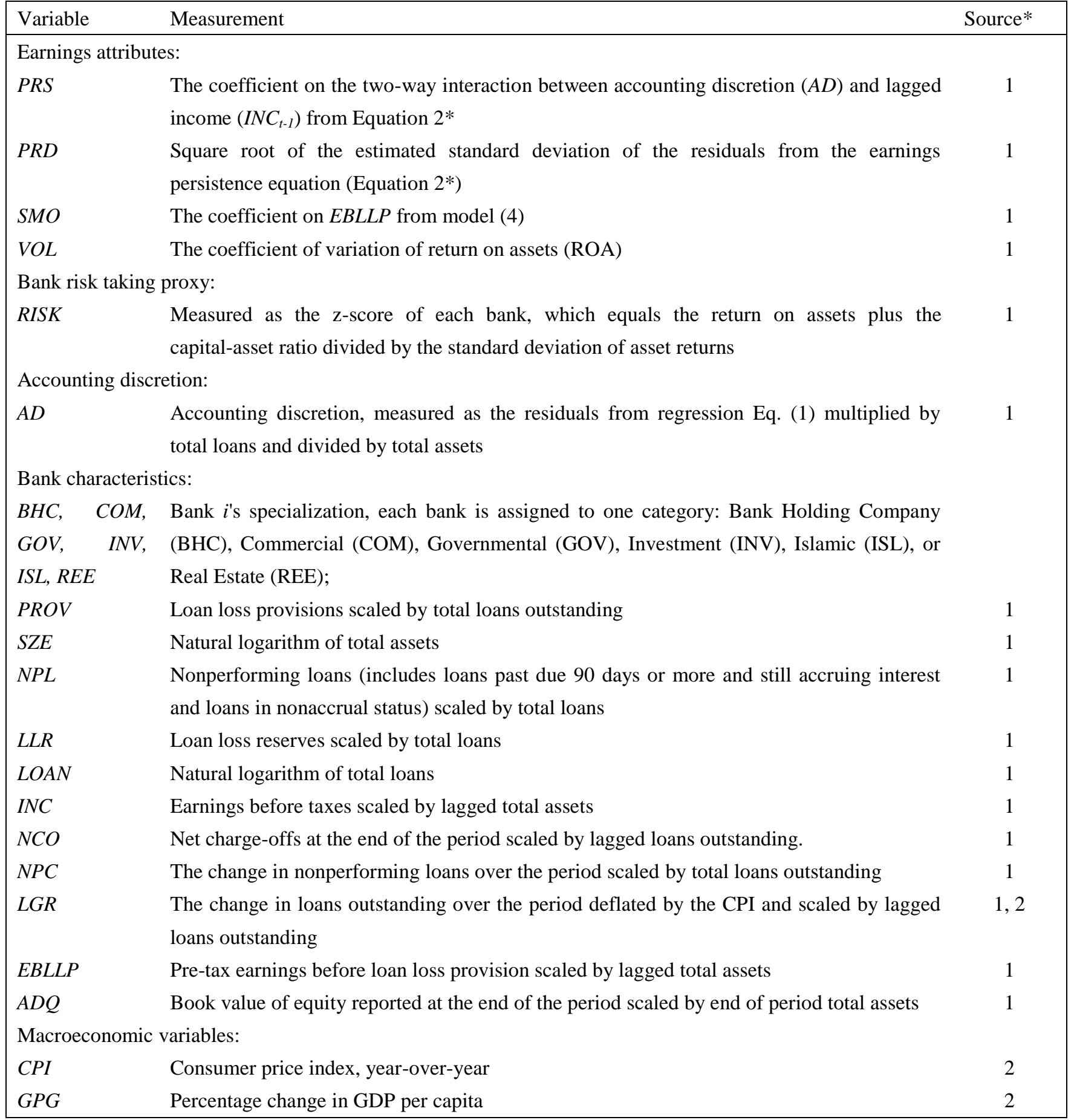

* Sources: Bankscope, 1; World Development Indicators Database, 2 